\title{
The role of dispersal for shaping phylogeographical structure of flightless beetles from the Andes
}

\author{
Sofia I. Muñoz-Tobar ${ }^{\text {Corresp., } 1,2}$, Michael S. Caterino ${ }^{1}$ \\ 1 Department of Plant \& Environmental Sciences, Clemson University, Clemson, SC, United States \\ 2 Escuela de Ciencias Biológicas, Pontificia Universidad Católica del Ecuador, Quito, Pichincha, Ecuador \\ Corresponding Author: Sofia I. Muñoz-Tobar \\ Email address: munoztobarsofia@gmail.com
}

Background. Páramo is a tropical alpine ecosystem present in the northern Andes. Its patchy distribution imposes limits and barriers to specialist inhabitants. We aim to assess the effects of this habitat distribution on divergence across two independently flightless ground beetle lineages, in the genera Dyscolus and Dercylus.

Methods. One nuclear and one mitochondrial gene from 110 individuals from 10 sites across the two lineages were sequenced and analyzed using a combination of phylogenetics, population genetic analyses and niche modelling methods.

Results. The two lineages show different degrees of population subdivision. Low levels of gene flow were found in Dyscolus alpinus, where one dominant haplotype is found in four out of the six populations analyzed for both molecular markers. However, complete population isolation was revealed in species of the genus Dercylus, where high levels of differentiation exist at species and population level for both genes. Maximum entropy models of species in the Dercylus lineage show overlapping distributions. Still, species distributions appear to be restricted to small areas across the Andes.

Conclusion. Even though both beetle lineages are flightless, the dispersal ability of each beetle lineage appears to influence the genetic diversity across fragmented páramo populations, where $D$. alpinus appears to be a better disperser than species in the genus Dercylus. 
1 The role of dispersal for shaping phylogeographical

2 structure of flightless beetles from the Andes

3

4

5

6

Sofía I. Muñoz-Tobar ${ }^{1,2}$ and Michael S. Caterino ${ }^{1}$

${ }^{1}$ Department of Plant \& Environmental Sciences, Clemson University, Clemson, SC, USA

${ }^{2}$ Escuela de Ciencias Biológicas, Pontificia Universidad Católica del Ecuador, Quito, Ecuador

Corresponding Author:

Sofía Muñoz-Tobar ${ }^{1}$

Av. 12 de octubre 1076 y Roca, Quito, Pichincha,170525, Ecuador

Email address: munoztobarsofia@gmail.com

\section{ABSTRACT}

Background. Páramo is a tropical alpine ecosystem present in the northern Andes. Its patchy distribution imposes limits and barriers to specialist inhabitants. We aim to assess the effects of this habitat distribution on divergence across two independently flightless ground beetle lineages, in the genera Dyscolus and Dercylus.

Methods. One nuclear and one mitochondrial gene from 110 individuals from 10 sites across the two lineages were sequenced and analyzed using a combination of phylogenetics, population genetic analyses and niche modelling methods.

Results. The two lineages show different degrees of population subdivision. Low levels of gene flow were found in Dyscolus alpinus, where one dominant haplotype is found in four out of the six populations analyzed for both molecular markers. However, complete population isolation was revealed in species of the genus Dercylus, where high levels of differentiation exist at species and population level for both genes. Maximum entropy models of species in the Dercylus lineage show overlapping distributions. Still, species distributions appear to be restricted to small areas across the Andes.

Conclusion. Even though both beetle lineages are flightless, the dispersal ability of each beetle lineage appears to influence the genetic diversity across fragmented páramo populations, where D. alpinus appears to be a better disperser than species in the genus Dercylus. 


\section{INTRODUCTION}

The distribution of a species is determined by environmental conditions, ecological interactions of species, and dispersal dynamics. In particular, the dispersal ability of species plays an important role in determining species ranges and biogeographical patterns (Lester et al., 2007). The evolution of wings in insects is considered a major factor in their success and diversity (Stone \& French, 2003; Nicholson, Ross \& Mayhew, 2014), since it has allowed them to avoid predators, capture prey, and disperse (Stone \& French, 2003). Yet, the secondary loss and reduction of wings is recorded across many insect lineages (Wagner \& Liebherr, 1992), and wing length polymorphisms in insects, from reduction to complete loss of wings and wing muscles, appear to have strongly influenced dispersal and biogeographical patterns in these lineages (Gutierrez \& Menendez, 1997; Mcculloch, Wallis \& Waters, 2017; Ikeda, Nishikawa \& Sota, 2012).

Flightlessness has been recorded in insect faunas in stable habitats such as oceanic islands and caves (Darwin, 1859; Wagner \& Liebherr, 1992), as well as in species that live in harsh environments, like polar and alpine regions (Somme \& Block, 1991). The mechanism of selection against wings in beetles was hypothesized by Darwin (1859; pp. 135-136), based on the observation of beetles from an oceanic island, where flight could cause displacement due to high wind in open areas. It has also been suggested that maintaining functional wings is energetically expensive (Darlington, 1943; den Boer et al., 1979). Studies across beetle species show that most winged species appear to have a wider geographical distribution than brachypterous species (Gutierrez \& Menendez, 1997; Ikeda, Nishikawa \& Sota, 2012). Therefore, the loss of flight capabilities is predicted to promote allopatric speciation due to limited dispersal power (Ikeda, Nishikawa \& Sota, 2012). Still, beetle communities in montane regions are often composed of winged species (macropterous), species with reduction of wings (brachypterous), species with very small wings (micropterous), as well as wing-polymorphic species that exhibit a range in the length of wings (Nilsson, Petterson \& Lemdahl, 1993; Moret, 2005).

Flightlessness in carabid beetles has been the focus of several studies, some of which support the idea that wing loss promoted genetic isolation across populations (Sota \& Nagata, 2008; Homburg et al., 2013). However, lack of genetic structure has also been reported for other 
61 flightless ground beetles, where populations appear to maintain low levels of gene flow

62 (Chatzimanolis \& Caterino, 2007). In a comparative study across five carabid lineages in the

63

64 eastern United States, some winged and wingless forms were found to have comparable levels of genetic heterogeneity (Liebherr, 1988). This broad range of observations suggests that population differentiation results from a combination of factors, including dispersal capability, but also discontinuity of the habitat, resource availability, and population sizes (Liebherr, 1988; Vogler, 2012).

The higher elevations of the northern Andes host a unique plant community known as páramo. Limited to elevations above $3000 \mathrm{~m}$, páramo is patchily distributed among the many higher peaks and volcanos in the range. Páramo contains a high number of endemic species, which are mostly are restricted to small elevational ranges (above $2800 \mathrm{~m}$; Luteyn, 1999; Sklenář, Dušková \& Balslev, 2011; Madrinán, Cortés \& Richardson, 2013; Sklenáŕ, Hedberg \& Cleef, 2014). Habitat loss due to various anthropogenic impacts is a major concern for the conservation of this ecosystem (Hofstede et al., 2002), but little consensus has emerged on the effects of habitat isolation on diversification of this region's biota. Phylogenetic studies of high elevation species from the Andes have been few and mostly centered on plants (Madriñán, Cortés \& Richardson, 2013; Hughes \& Atchison, 2015; Gómez-Gutiérrez et al., 2017). These show mostly high diversification rates, and in some instances, signs of the contraction and expansion of the páramo during Quaternary glaciations affecting some plant lineages (GómezGutiérrez et al., 2017). For the few vertebrate species studied, varied patterns of differentiation are observed (Páez-Moscoso \& Guayasamin, 2012; Rodríguez Saltos \& Bonaccorso, 2016), and few insects or other invertebrate species have been examined (Hines, 2008; Elias et al., 2009; Polato et al., 2018). Analyses of aquatic insects from páramo show these insect lineages possess narrow thermal tolerance ranges, which appear to promotes high speciation rates (Polato et al., 2018).

In this study we focused on two flightless ground beetle (Coleoptera: Carabidae) lineages from páramo. Most of the ground beetles present in páramo are micropterous ( $76 \%$ of species), with only few macropterous and brachypterous species reported (Moret, 2005). To examine the effect of fragmentation across páramo patches we examined two distinct lineages. The first, Dyscolus alpinus Chaudoir, 1878 (Coleoptera, Carabidae, Harpalinae, Platynini), is a micropterous species present in the northern and central portion of the Ecuadorian Andes, 
92 between 2750-4200 m, in páramo, subpáramo and montane forest (Moret, 2005). Members of 93 the genus Dyscolus Dejan, 1831 are mainly neotropical, from Mexico to Argentina, with some representatives present in the southern United States (Moret, 2005; Bousquet, 2012). Of 320 total species in the genus Dyscolus, 89 species are known from Ecuadorian páramo (2750- $4200 \mathrm{~m})$. The second beetle lineage assessed comprises multiple species in the genus Dercylus Laporte de Castelnau, 1832 (Coleoptera, Carabidae, Harpalinae, Licinini). Dercylus is a new world genus with 35 species (Bousquet, 2012), including five species from the Ecuadorian Andes (Moret \& Bousquet, 1995; Moret, 2005). All Ecuadorian species belong to the subgenus Linodercylus Kuntzen, 1912, all of which are micropterous and occurring in montane forest and páramo between 2700-4200 m. Species sampled for analyses include three described species: $D$. orbiculatus Moret \& Bousquet, 1995, D. praepapilatus Moret \& Bousquet, 1995, and D. cordicollis (Chaudoir, 1883), and two as-yet unidentified (probably undescribed) species from the Ecuadorian páramo.

The aim of this study is to analyze the effects of montane isolation in these two flightless beetle lineages from páramo, and to ask how their phylogenetic structure and population connectivity have been affected by potential geographical barriers, their dispersal abilities, and their ages of divergence. We analyzed two molecular markers, cytochrome oxidase gene I (COI) and carbamoyl phosphate synthetase 2 (CAD), alone and combined, to determine phylogenetic relationships among individuals for each lineage, population genetic diversity and structure, and approximate ages of each clade with the use of molecular clocks. In addition to the analyses of the molecular data, geographic information was used to generate models of species distribution as a way of assessing habitat continuity.

\section{MATERIALS \& METHODS}

\section{Study area}

The study area encompassed the Ecuadorian Andes, where all the sampling took place above 3100 meters in the páramo ecosystem. The selection of sites was based on previous records of occurrence of the target taxa, and potential geographical barriers. Some of these potential barriers include: dry valleys, rivers, faults, and the east/west split of the Andes mountain range (Krabbe, 2008; Guayasamin et al., 2010; Quintana et al., 2017). In particular, the Pastaza, Chanchan, and Mira rivers, and their corresponding valleys, appear to limit the 
122 distributions of some bird, amphibian and plant species (Krabbe, 2008; Guayasamin et al., 2010;

123 Quintana et al., 2017). The Pallatanga fault, a prominent NE-SW strike-slip fault crossing the

124

125

126

127

128

129

130

131

132

133

134

135

136

137

138

139

140

141

142

143

144

145

146

147

148

149

150

151 western cordillera (Baize et al., 2015), may also affect lineage dispersal. The most prominent geographic divide considered in this study was the split of the Ecuadorian Andes into east and west cordilleras, associated with limits of distribution in several vertebrate and plant species (Chaves et al., 2007; Guayasamin et al., 2010; Sklenář et al., 2011).

\section{Sample collection}

Ground beetle specimens were collected at 8 sites along the Ecuadorian Andes, between 3100 to $4000 \mathrm{~m}$ in national parks during two field seasons in the summers of 2015 and 2016 (Figs. 1, Table 1). Permissions necessary for the collection of samples were previously obtained through the Ministry of Environment of Ecuador (MAE), permit number MAE-DNG-ARGGCM-2014-004). Dyscolus alpinus was found in 6 out of the 8 sites sampled (Fig. 1A), while Dercylus specimens were collected in 5 sites (Fig. 1B). Adult beetles were collected into 100\% EtOH using three methods: manual collection (underneath rocks and on vegetation), pitfall trapping, using two $100 \mathrm{~m}$ transects ( 1 trap every $10 \mathrm{~m}$ ), where traps ran for 2-3 days; and through the collection of leaf litter samples from the páramo floor. Three samples of leaf litter were collected per site, and were processed in the lab using Berlese funnels. Ground beetles were identified using Moret's (2005) taxonomic keys. An additional sample was provided and identified by Pierre Moret as Dercylus cordicollis (SIMT265) from Cotacachi, this sample was included for the analysis of $D$. cordicollis populations. Outgroup taxa were chosen based on availability of fresh material and taxa considered closely related carabid lineage within the Harpalinae. Outgroup taxon sampling included twelve taxa: two were collected in the Ecuadorian páramo; six taxa were collected in the southeastern United States; and four additional samples were retrieved from Genbank (KR604910, Supplementary Table S1). Species in the genus Platynus, Agonum and Incagonum were used as outgroups in the analyses of Dyscolus. Amara, Oodes, Dicaelus, Sarticus, Notonomus and Loxodactylus were used as outgroups in the analyses of Dercylus (Supplementary Table S1). Voucher specimens will be deposited in the Museo de Zoología de la Pontificia Universidad Católica del Ecuador (QCAZ) after the study is completed.

\section{DNA extraction, sequencing, and alignment}


152

153

154

155

156

157

158

159

160

161

162

163

164

165

166

167

168

169

170

171

172

173

174

175

176

177

178

179

180

181

Genomic DNA was extracted from 110 specimens (with an average of 10 individuals per site, per species) using GeneJet's Genomic DNA Purification Kit (Thermo Fisher Scientific, Vilnius, Lithuania) following the manufacturer's instructions. A fragment of the mitochondrial cytochrome c oxidase subunit I (COI) gene was amplified using the primers TL2-N-3014 (5'TCCAATGCACTAATCTGCCATATTA-3' and C1-J-2183 (5'-

CAACATTTATTTTGATTTTTTGG-3'; Simon et al., 1994) and the amplification profile described in Caterino \& Tishechkin (2014). One nuclear coding gene, and carbamoyl phosphate synthetase 2 (CAD), was amplified using the primers CD439F (5'-

TTCAGTGTACARTTYCAYCCHGARCAYAC-3') and CD688R (5'TGTATACCTAGAGGATCDACRTTYTCCATRTTRCA-3'). Heminested PCRs were done for difficult samples, using CD439F (5'-TTCAGTGTACARTTYCAYCCHGARCAYAC-3') and CD1098R (5'- TTNGGNAGYTGNCCNCCCAT-3) following Wild \& Maddison (2008). All PCRs were performed in $25 \mu \mathrm{l}$ reactions, containing $17.5 \mu \mathrm{l}$ water, $2.5 \mu \mathrm{l} 10 \mathrm{x}$ buffer, $0.5 \mu \mathrm{l}$ dNTPs, $0.75 \mu 1 \mathrm{MgCl} 2,0.1 \mu \mathrm{l}$ DreamTaq DNA Polymerase (Thermo Fisher Scientific) and $1 \mu 1$ of each primer $(5 \mathrm{~nm})$. PCR products were cleaned using ExoSAP-IT (USB/Affymetric, CA, U.S.A). Sequencing was done commercially by Macrogen USA, Inc. (Rockville, MD, U.S.A).

DNA sequences were edited using Geneious R8 (Biomatters Ltd., Auckland NZ) and aligned in MAFFT v.7 (Katoh \& Standley, 2013) together with sequences from outgroups. Models of sequence evolution were tested using JModeltest 2.0 (Darriba et al., 2012) for each data set, where GTR $+\mathrm{I}+\mathrm{G}$ model was in the $100 \%$ confidence interval for both COI and CAD data.

\section{Genetic diversity and population structure}

The levels of genetic diversity were calculated using Arlequin 3.5.2.2 (Excoffier \& Lischer, 2010) and DnaSP (Rozas et al., 2003) using the default settings. Groups analyzed were: 1: Dyscolus alpinus; 2: Dercylus orbiculatus; and 3: Dercylus species together (D. orbiculatus, D. cordicollis, D. praepilatus and Dercylus sp. from Atillo and Cotacachi) in order to contrast inter- and intrapopulation variability. Parameters estimated included: estimated haplotype diversity (h), nucleotide diversity $(\pi)$, number of polymorphic sites $(\mathrm{S})$, number of migrants per generation (Nm), and Tajima's D neutrality test statistic (D). $\Phi_{\mathrm{ST}}$ values were calculated to assess the population structure, while an analysis of the molecular variance (AMOVA) was performed to test the influence of geographical barriers, including the rivers, dry valleys 
182

183

184

185

186

187

188

189

190

191

discussed above, and the division between populations of eastern and western cordilleras. A Mantel test of correlation between genetic and geographic distances was performed using 1000 randomizations (also in Arlequin). Lastly, Structure 2.3.4. (Pritchard, Stephens \& Donnelly, 2000) was used to estimate the number of populations (K), using no admixture for the mtDNA and admixture for the nuclear gene. Ten iterations were run per potential $\mathrm{K}$, and the presence of one to eight populations were tested for both beetle lineages.

\section{Phylogenetic analyses and the molecular clock}

Phylogenetic analyses were performed to determine relationships among individuals for each lineage and among lineages. To explore marker-specific effects, mitochondrial and nuclear data sets were analyzed initially analyzed separately, but combined data were used to generate the most robust hypotheses for each beetle lineage using MrBayes 3.2 (Huelsenbeck \& Ronquist, 2001) and RAxML version 8.2.8 (Stamatakis, 2014). The analyses performed in MrBayes incorporated a GTR + G + I model, with two independent runs through 1,000,000 generations, with trees sampled every $100^{\text {th }}$ generation. For RAxML (version 8.2.8; Stamatakis, 2014), analyses were launched from Mesquite's Zephyr package (Maddison \& Maddison, 2015) with 1000 bootstrap replicates using default settings. In addition to these phylogenetic inferences, the number of haplotypes was estimated using DnaSp (Rozas et al., 2003) and haplotype networks were inferred with TCS (Clement et al., 2000), using default settings.

To understand the timing and rate of diversification for each ground beetle lineage, divergence times were estimated using an uncorrelated relaxed clock in BEAST 2.0 (Bouckaert et al., 2014) using the COI and CAD data matrixes. For Dyscolus alpinus, one point of fossil calibration was used to designate minimum node ages, using a log-normal distribution and enforced monophyly. This fossil represent taxa within the same tribe as Dyscolus (Platynini): a fossil of Limodromus from the late Eocene (37.2- 33.9 Mya), of Baltic origin (Schmidt, 2015). The divergence time for the Dercylus lineage was also estimated using two points of fossil calibration: Amara (Harpalinae: Zabrini) from the Middle Eocene (44.1 Mya), of Baltic origin (Larsson, 1978), and Pterostichus walcotti (Harpalinae: Pterostichini) from the Eocene (37.2 to 33.9 Mya) of Teller County, Colorado (Scudder, 1900). In addition to fossil calibrations, substitution rates presented Andújar et al. (2012) for COI were used in both analyses for comparison. Log files from Beast were examined in Tracer 1.5 
212 (http://tree.bio.ed.ac.uk/software/tracer/) to ensure effective samples sizes (ESS). Trees were

213 visualized in TreeAnnotator 2.0.02 (http://beast.bio.ed.ac.uk), using maximum clade credibility

214 (MCC) after a 10\% burn-in.

215 Maximum entropy models for species in the genus Dercylus

216

217

218

219

220

221

222

223

224

225

226

227

228

229

230

231

232

233

234

235

236

237

238

239

240

The ecological niche of each species of Dercylus was modeled to determine if species distribution overlapped, using present bioclimatic variables at 2.5' spatial resolution (WorldClim v.1.4; Fick \& Hijmans, 2017) with the use of MAXENT 3.3.3 (Phillips, Anderson \& Schapire, 2006). Dercylus from Cotacachi and Atillo were excluded from these analyses given the few records available. For other species of Dercylus, sites mentioned in Moret (2005) were georeferenced using GeoLocate (Rios \& Bart, 2010) and combined with the distribution data generated in this study. A total of 41 occurrence records were gathered for analyses. The model of distribution was based on five bioclimatic variables: BIO1 = Annual Mean Temperature, $\mathrm{BIO} 2=$ Mean Diurnal Range $($ Mean of monthly $(\max$ temp $-\min$ temp $)), \mathrm{BIO} 5=\mathrm{Max}$

Temperature of Warmest Month, BIO6 = Min Temperature of Coldest Month, BIO12 = Annual Precipitation, $\mathrm{BIO} 13=$ Precipitation of Wettest Month and BIO14 = Precipitation of Driest Month. The analyses ran for ten replicates of 500 iterations and using a 10\% training presence, using the default settings for the convergence threshold $\left(10^{-5}\right)$. For each species, the output from the average run was reclassified using ArcMap 10.4.1 (ESRI, 2016) with a 10\% threshold. Model performance was evaluated using the area under the curve (AUC) calculated by MAXENT, where values between 0.7 and 0.9 indicated a good discrimination (Swets, 1988).

\section{RESULTS}

\section{Genetic diversity and population structure in Dyscolus alpinus}

The portion of the COI gene analyzed for D. alpinus was $767 \mathrm{bp}$ long, with 41 parsimony informative sites making up 6 haplotypes (Fig. 2A; GenBank accessions MK440253 to MK440258). Haplotype 1 is the most widespread across populations, found in four of six sites (Fig. 2A). Unique haplotypes were recorded from Atillo (H3), Mojanda (H5) and Cayambe (H6, Fig. 2A). Haplotype diversity (h) is shown in Table 2 for each population, where Mojanda exhibits the highest haplotypic diversity $(\mathrm{h}=0.71)$. The overall nucleotide diversity of COI was low $(\pi=0.00-0.01)$. Structure analyses tended to overestimate the number of populations; results 
241 from multiple simulations show that the number of populations using this data set is one $(\mathrm{K}=1)$.

242 Results from the neutrality test for the overall values $(\mathrm{D}=-0.81, \mathrm{p}=0.42 ; \mathrm{F}=-2.16, \mathrm{p}=0.40)$, as 243 well as on most populations are not significant (Table 2). Cayambe and Atillo were exceptions, 244 but these did not exhibit a high proportion of rare alleles, often associated with population 245 expansion (Fig. 2A). Additionally, a Mantel test showed no correlation $\left(p=0.13, R^{2}=0.08\right)$ 246 between genetic $\left(\Phi_{\mathrm{ST}}\right)$ and geographical distances.

The CAD data set for D. alpinus spanned $744 \mathrm{bp}$, with 64 parsimony informative sites. These represented five haplotypes (GenBank accessions MK440260 to MK440264), with no heterozygote individuals observed. Haplotype 1 is found in four of the six populations. Unique haplotypes were recorded from Atillo (H4) and Cayambe (H5). Haplotype networks for both genes show that most haplotypes are present at multiple sites (Fig. 2B). The overall haplotypic (h) and nucleotide diversity was low for CAD data set (Table 2). Among all the sites analyzed, Mojanda showed the highest haplotypic diversity $(\mathrm{h}=0.91)$. Structure analyses of the nuclear data set showed three populations $(\mathrm{K}=3)$. Similar to the results from the mitochondrial data, most neutrality tests using $\mathrm{CAD}$ (overall value $\mathrm{D}=-0.86 ; \mathrm{p}=0.36 ; \mathrm{F}=5.97, \mathrm{p}=0.40$ ) were not significant, with Cayambe and Pichincha as exceptions. Again, however, these apparent exceptions exhibit few haplotypes, inconsistent with a population expansion scenario. Results from the Mantel test show there was no correlation between genetic and geographic distances $(\mathrm{p}=0.81, \mathrm{R} 2=0.01)$.

The AMOVA of nuclear and mitochondrial data for Dyscolus alpinus shows that most of the variation occurs within populations (Table 3). These results seem to contrast with the overall $\phi_{\mathrm{ST}}$ values $\left(\mathrm{COI} \phi_{\mathrm{ST}}=0.54 ; \mathrm{CAD} \phi_{\mathrm{ST}}=0.26\right)$, which suggest moderate levels of population subdivision among populations. When $\phi_{\mathrm{ST}}$ values were compared on a population-by-population basis, some genetic differentiation was found among populations (Table 4, Fig. 3). COI data exhibited higher overall genetic differentiation between sites $\left(\phi_{\mathrm{ST}}=0.32-0.90\right.$; Table 4$)$. Some exceptions are found between sites that are closer in distance (less than $36 \mathrm{~km}$ ), such as Cayambe-Mojanda (separated by $30 \mathrm{~km}$ ): $\phi_{\mathrm{ST}}=0.10$, and La Virgen-Pichincha (separated by 36 $\mathrm{km}): \phi_{\mathrm{ST}}=-0.10$. The CAD data set shows lower genetic differentiation among all populations of D. alpinus (Table 4). However, higher $\phi_{\mathrm{ST}}$ values are observed when Cashca Totoras is compared with the other sites $\left(\phi_{\mathrm{ST}}=0.5-0.65\right.$, Fig. 3$)$, except when compared to Cayambe $\left(\phi_{\mathrm{ST}}=\right.$ -0.08). The overall number of migrants between Dyscolus populations $(\mathrm{Nm}=0.31)$ indicates that 
272 there is population subdivision across sites. Higher levels of genetic connectivity were observed

273 between Mojanda and Cayambe $(\mathrm{Nm}=1.79)$, results that are also supported by the low $\phi_{\mathrm{ST}}$ values 274 between these two sites (Table 4).

275 Genetic diversity and population structure in species of the genus Dercylus

276

277

278

279

280

281

282

283

284

285

286

287

288

289

290

291

292

293

294

295

296

297

298

299

300

301

In the case of Dercylus species, the portion of the COI gene analyzed was $776 \mathrm{bp}$, with 76 parsimony informative sites constituting 16 haplotypes (GenBank accessions MK440220 to MK440235). No haplotypes were shared among sites (Fig. 4A), and overall nucleotide diversity within these species is low $(\pi=0.00-0.01$; Table 2$)$. Eight haplotypes were recorded for populations of $D$. orbiculatus, whereas two haplotypes were recovered from $D$. cordicollis. The individual sampled from Cotacachi represents a distinct lineage of Dercylus closely related to $D$. cordicollis, based on the TCS analyses and phylogenetic inference, though only one haplotype was found. For specimens of D. praepilatus from Salinas, one haplotype was recorded, while four haplotypes were recorded from specimens collected from the locality of Atillo. Based on the morphological similarity with D. orbiculatus, specimens from Atillo were thought to be another population of $D$. orbiculatus; however, based on haplotype designation and other phylogenetic analyses, this population appears to be a distinct lineage/species of Dercylus. Haplotype diversity indices are shown in Table 2 for each species and population, where populations of $D$. orbiculatus from Culebrillas show the highest haplotypic diversity $(\mathrm{h}=0.86)$ among Dercylus species and populations. Structure analyses of D. orbiculatus individuals all resolved as one population, even though the two sites do not share haplotypes. These analyses were also performed for the entire clade, and one population was found $(K=1)$. Neutrality test values were not significant (overall value $\mathrm{D}=0.26, \mathrm{p}=0.77 ; \mathrm{F}=0.89, \mathrm{p}=0.44$ ), with the exception of the population of $D$. orbiculatus from Culebrillas, for which significantly positive D and Fs were found (Table 2). Lastly, the Mantel test performed with $\phi_{\mathrm{ST}}$ and geographic distances show no significant correlation $\left(\mathrm{R}^{2}=0.05, \mathrm{p}=0.3\right)$ between genetic and geographical distances.

The portion of the CAD gene amplified for Dercylus species was 669 bp with 24 parsimony informative sites (GenBank accessions MK440236 to MK440251). A total of 13 alleles were identified across the Dercylus lineage and the overall nucleotide diversity was low $(\pi=0.00-0.02)$. Four alleles were recovered from $D$. orbiculatus populations, and three alleles from D. cordicollis, with one shared with Dercylus from Cotacachi (H5, Fig. 4B). Four alleles 
302 were identified in the population of Dercylus from Atillo, and three from D. praepilatus. Two 303 alleles were shared between D. praepilatus and Dercylus sp. from Atillo (H8 and H11; Fig. 4B).

304 The highest allele diversity is recorded for the Dercylus sp. from Atillo, followed by $D$.

305

306

307

308

309

310

311

312

313

314

315

316

317

318

319

320

321

322

323

324

325

326

327

328

329

330

331 orbiculatus from El Cajas and D. cordicollis (Table 2). Structure analyses for D. orbiculatus populations alone showed only one population $(\mathrm{K}=1)$, whereas results from the analyses of the whole clade show five distinct populations $(K=5)$, corresponding to each species. Neutrality tests supported significantly positive Fs for D. cordicollis from Pichincha (Table 2). Results from the Mantel test show no significant correlation $\left(\mathrm{p}=0.8, \mathrm{R}^{2}=0.02\right)$ between genetic $\left(\phi_{\mathrm{ST}}\right)$ and geographical distances.

The AMOVA showed that most of the genetic variation was found among groups when testing the effect of geographical barriers (Table 5). The high variation among groups is consistent with the existence of multiple species, since species in this genus do not have widespread distributions, with the exception of $D$. orbiculatus, occurring across the southern Ecuadorian Andes (Fig. 1; Moret, 2005). The highest percentage of variation in the AMOVA when parsing the data by species was seen across the Chimbo and Chanchan dry valleys and rivers, which overlap with another potential geographical barrier, the Pallatanga depression. These results were also supported by the overall $\phi_{\mathrm{ST}}$ values, which show high levels of differentiation among species and sites $\left(\mathrm{COI} \phi_{\mathrm{ST}}=0.89 ; \mathrm{CAD} \phi_{\mathrm{ST}}=0.95\right)$. A high level of genetic differentiation was also observed when $\phi_{\text {ST }}$ values were compared between populations and species in COI data set (Table 6). In this data set, the lowest $\phi S T$ values were observed between populations of $D$. orbiculatus from Cajas and Culebrillas $\left(\phi_{\mathrm{ST}}=0.50\right)$.

In the case of the nuclear coding gene $C A D$, the overall value of $\phi_{\mathrm{ST}}\left(\phi_{\mathrm{ST}}=0.93\right)$ shows high levels of population differentiation. When each population was compared against each other, we found moderate to complete population subdivision between some sites $\left(\phi_{\mathrm{ST}}=0.77-\right.$ 1.00, Table 6), particularly when comparing against populations of D. orbiculatus from Cajas or Culebrillas. Lower $\phi_{\text {ST }}$ values were found between the two populations of $D$. orbiculatus Cajas and Culebrillas $\left(\phi_{\mathrm{ST}}=0.10\right)$, as well as between Pichincha and Cotacachi $\left(\phi_{\mathrm{ST}}=0.00\right)$, Pichincha and Salinas $\left(\phi_{\mathrm{ST}}=0.00\right)$, Salinas and Atillo $\left(\phi_{\mathrm{ST}}=0.03\right)$, and Salinas and Cotacachi $\left(\phi_{\mathrm{ST}}=0.00\right)$. The number of migrants per generation was calculated for two populations of $D$. orbiculatus (Cajas and Culebrillas), which revealed low gene flow $(\mathrm{Nm}=0.39)$. 
332

333

334

335

336

337

338

339

340

341

342

343

344

345

346

347

348

349

350

351

352

353

354

355

356

357

358

359

360

361

\section{Phylogenetic analyses and divergence time estimations}

Phylogenetic analyses were conducted separately for each gene data set using Bayesian and Maximum Likelihood (ML) methods. Analyses of the two fragments for D. alpinus yields similar resolution (Fig. 5A vs. 5B), with Dyscolus sp. (SIMT208) as sister to the D. alpinus clade (Fig. 5A). These results are consistent with the TCS haplotype network, which shows most samples are contained within one network, with the exception of COI haplotype 6 (SIMT208H6, Fig. 2A). Most haplotypes are present at multiple sites (Fig. 5A), with only two unique haplotypes (Atillo-H3 and Mojanda-H5). Haplotype 1 is found at five of six sampling sites (Mojanda, Cayambe, Pichincha, La Virgen, Cashca Totoras); haplotype 2 and haplotype 4 are each found at two (Atillo, Mojanda and Cayambe, Mojanda, respectively; Fig. 2A). The highest haplotypic diversity was found at Mojanda with 4 haplotypes (H1, H2, H4, H5), while the lowest was at Cashca Totoras and Pichincha with only the widespread H1 haplotype found at each site. A similar pattern was recovered for CAD. First, CAD also suggested that SIMT208 from Cayambe represented a distinct Dyscolus species (Fig. 5B). Within D. alpinus, four CAD haplotypes were recorded (Fig. 5B). Most sites yielded haplotype 1 (Mojanda, Cayambe, Pichincha, La Virgen, Cashca Totoras, Fig. 2B), with only one unique haplotype (H4) observed from an individual from Atillo. The Mojanda population showed the highest haplotypic diversity (H1, H2, H3), whereas Pichincha (H1) and Cashca Totoras (H1) each only revealed one widespread haplotype. A relaxed molecular clock was used on the combined matrix for $D$. alpinus to calculate divergence time estimates for the clade (Fig. 6). These analyses suggest that the D. alpinus clade originated during the Miocene 6.09 Mya (1.26-13.64 Mya). The timing of splitting-events for the D. alpinus clade (14.33 Mya, with a confidence interval of 3.63-27.46 Mya; Fig. 6) is slightly older than most páramo plant species (2-5 Mya; Madriñán et al., 2013), but contemporary with the evolution of highland species in the northern Andes mountain chain, which arose during the Miocene (Weir 2006, Hines 2008).

For Dercylus, the two genes reveal slightly different patterns (Fig. 7A-B). COI tree suggests that most species and sites are monophyletic (Fig. 7A), with D. orbiculatus the exception, appearing as a paraphyletic grade. The CAD gene tree shows less structure associated with site and species, since multiple alleles are shared among species, for example, between $D$. praepilatus and Dercylus sp. from Atillo (H8, H11), and between D. cordicollis and Dercylus sp. 
362 from Cotacachi (H5; Fig. 4B). Yet, in CAD, Dercylus orbiculatus appears as a distinct clade,

363 supported by bootstrap and posterior probability values (Fig. 7B).

364

365

366

367

368

369

370

371

372

373

374

375

376

377

378

379

380

381

382

383

384

385

386

387

388

389

390

The analysis of the combined matrix (COI and CAD; Fig. 8) exhibits clearer resolution among species and populations of Dercylus, though D. orbiculatus appears again as a grade, as in the COI tree. A relaxed molecular clock based on the combined data set shows that the Dercylus clade originated during the Oligocene 29.81 Mya, with a confidence interval of 12.4550.38 Mya. Thus, most of the sampled species in this study originated prior to the evolution of páramo, with D. orbiculatus (10.74-13.5 Mya, confidence interval of 1.10-28.58 Mya), Dercylus from Cotacachi (16.39 Mya, confidence interval of 3.60-24.38 Mya) and Dercylus sp. from Atillo (6.04 Mya, originating confidence interval of 1.13-12.90 Mya) during the Miocene (16.4- 6.04 Mya). Dercylus cordicollis, on the other hand, originated in the Pliocene (3.68 Mya, confidence interval of 0.00-6.96 Mya), and D. praepilatus (2.38 Mya, confidence interval of 0.01-7.23 Mya) in the Pleistocene. Only these last two diversifications were contemporary with the diversification of most páramo plants (2-5 Mya, Madrinán et al., 2013).

\section{Niche modeling for species in the genus Dercylus}

The ecological niche model for the three described species of Dercylus showed a high predictive ability under a random model, with AUC values between 0.998-0.999. Populations of this ground beetle lineage are mainly present in the Andean region of Ecuador, with potentially overlapping distributions (Fig. 9). Compared to other species analyzed, the maximum entropy model for D. orbiculatus shows that this species is present at high elevation, but its distribution also extends to lower elevations, especially towards the south. In contrast, D. praepilatus has the smallest potential distributional range. Lastly, niche modeling also revealed that suitable habitats for species of this genus also extend into to the Andean regions of Colombia and Peru. To test if the distribution of the species extends into these areas, further sampling is needed.

\section{DISCUSSION}

The effect of dispersal ability on population genetic structure and diversification represents a rich focus of study (Bohonak 1999). Insects, varying so broadly in body size and flight ability, have played a prominent role in such studies (Bruhl 1997, Gutierrez and Menendez 1997, Ikeda et al. 2012). Yet, apparently limited dispersal ability (through wing reduction/loss) 
391 has been associated with varied results, from high phylogeographic structure (Gutierrez and

392 Menendez 1997, Ikeda et al. 2012), to low levels of gene flow and only moderate structure (e.g.,

393 Chatzimanolis and Caterino 2007, Huang and Lin 2010). In tropical mountains, wingless and

394 wing dimorphic species dominate beetle communities (Erwin 1985, Ahn and Ashe 1996, Moret

395 2005), but the relationship between wing reduction and diversification in the tropical Andes has

396 been little explored. The present study is among a very few (e.g. Hines, 2008; Maddison, 2014;

397 De-Silva et al., 2016) focused on insects from the Andean region, an area characterized by its

398 high diversity (Myers et al. 2000, Veblen et al. 2007). Our analyses of two flightless ground

399 beetles from páramo show different degrees of population subdivision. Dyscolus alpinus, which

400 exhibits some wing polymorphism (from micropterous to brachypterous individuals), shows a

401 low haplotypic diversity across sampled populations. In Dercylus (entirely micropterous),

402 however, high levels of differentiation were found at the species and population levels. The

403 reasons for these differences are not entirely clear.

404 In Dyscolus alpinus, a dominant haplotype for each marker is found in four out of the six 405 populations analyzed, with one site (Mojanda) exhibiting unusually high diversity. The diversity 406 at this site could be associated with multiple colonization events due to dynamic habitat shifts 407 from volcanic activity dated prior to the Last Glacial Maximum (Mt. Mojanda and Mt. Fuya 408 Fuya, Robin et al., 2009), and periodic burns during the Holocene (Frederick et al. 2018). Even though most genetic variation occurs within populations of $D$. alpinus, some among-population genetic differentiation was also revealed, particularly comparing Cashca Totoras (site 4) to other sites. Some populations pairs on opposite sides of the cordillera also present high population structure (e.g. Pichincha - Atillo), but this not the case for most sites, so simple E-W and N-S groupings show minimal explanatory power. High $\phi S T$ values found among sites on the same side of the cordillera could have resulted from habitat discontinuity reinforced by the presence of major geographical barriers such as major rivers and dry valleys (Krabbe, 2008; Guayasamin et al., 2010; Quintana et al., 2017). For example, in the eastern cordillera the Atillo vs. Cayambe and La Virgen populations are separated by the Pastaza river, previously proposed as a limiting factor for some species in the Ecuadorian Andes (Krabbe 2008, Guayasamin et al. 2010). In addition to major rivers, the presence of lower elevation dry valleys appears to be contributing to higher structure between northern populations. This is the case for the Pichincha and Mojanda populations, located relatively close in distance $(\sim 47 \mathrm{~km})$, but separated by the Guayllabamba 
422 valley (Quintana, 2010). So, rapid changes in elevation and abiotic conditions over short

423 distances do appear to affect gene flow between sites. The dissimilarity in the results from

424

425

426

427

428

429

430

431

432

433

434

435

436

437

438

439

440

441

442

443

444

445

446

447

448

449

450

451

452 nuclear and mitochondrial data sets in the population genetic analyses is likely associated with differences in the rate of nucleotide change between these markers (Lin and Danforth 2004). The low levels of genetic variation in the CAD data set reflects the recent origin of the D. alpinus (6.32 Mya, Miocene), whereas the higher population structure in the COI data set probably results from both higher mutation rates and shorter coalescence times of mitochondrial DNA (Lin and Danforth 2004).

For the genus Dercylus represented here by multiple (described and undescribed) species, high levels of differentiation are reported at the species and population level for both genes. The mitochondrial marker showed no shared haplotypes among sites and species, whereas CAD showed three shared haplotypes, generally shared by proximate populations (Salinas+Atillo, and Pichincha+Cotacachi). Species in the genus Dercylus show smaller distributions (Moret 2005). However, results from niche modelling for three species of Dercylus using present conditions show that these species could have potentially overlapping distributions. Both dispersal ability and geographical barriers appear to be playing roles shaping the genetic diversities of Dercylus species. $\phi S T$ values were high even between populations of $D$. orbiculatus (Cajas and Culebrillas, divided E-W by the principal inter-Andean valley), sharing no haplotypes in either marker. It is, however, intriguing that the three CAD haplotypes at Culebrillas appear to be derived from the single common one at Cajas. This may be the basis for Structure only recovering one population $(\mathrm{K}=1)$ with $\mathrm{COI}$ and $\mathrm{CAD}$ sequences, suggesting that in the past these populations had higher connectivity levels. Based on AMOVA results, the Chimbo and Chanchan river valleys, which overlap with the Pallatanga fault (Baize et al. 2015), appear to be major geographical barriers for the members of Dercylus in the southern Ecuadorian Andes, separating distantly related species. The high mountains between Atillo and Culebrillas (Mt. Ayapungo and Mt. Coyay, above $4600 \mathrm{~m}$ ) also seem to have contributed towards the genetic heterogeneity seen in Dercylus in the eastern cordillera, considering the high $\phi S T$ values (Table 6) and the lack of shared haplotypes between these two sites (Fig. 4). Lastly, the combination of distance between sites and the presence of lower elevation dry valleys appear to have had a combined effect, separating D. cordicollis (Pichincha) and Dercylus sp. (from Cotacachi). Divergence time estimates show that the species in the Dercylus clade originated during the

Peer) reviewing PDF | (2019:03:35621:1:1:NEW 14 May 2019) 
453 Miocene, Pliocene and Pleistocene (16-2 Mya; Fig. 8), mostly during the Miocene prior to 454 appearance of páramo (2-5 Mya Pliocene and Plesitocene: Madriñán et al. 2013), with exception

455

456

457

458

459

460

461

462

463

464

465

466

467

468

469

470

471

472

473

474

475

476

477

478

479

480

481

of D. cordicollis (3.68 Mya, Pliocene) and D. praepilatus (2.38 Mya, Pleistocene).

While phylogenetic and population analyses of Dercylus largely support species distinctions, the status of D. orbiculatus (sampled from both Cajas and Culebrillas) is less clear.

It is resolved as a paraphyletic grade by COI, as well as in the combined data tree, but monophyletic by CAD, with strong support. While this difference may be a result of the difference in rate of nucleotide change between genes (Lin and Danforth 2004), divergences in mtDNA sequences are low $(0.25 \%)$, network analyses offer no indication that these should be considered distinct.

When results from these two flightless lineages were compared to the patterns observed in Pelmatellus columbianus, a macropterous ground beetle also present in páramo (MuñozTobar, in press), a common pattern for the distribution of the genetic diversity for ground beetles that live in páramo does not emerge. The flightless beetles analyzed here both have higher levels of population structure when compared to P. columbianus. Yet, even though both Dyscolus and Dercylus lineages are flightless, Dyscolus alpinus appears to be a better disperser than species in the genus Dercylus. Evidence for this was found in the levels of genetic connectivity between northern populations of $D$. alpinus that show some levels of gene flow (e.g. MojandaCayambe), perhaps facilitated by Quaternary glaciations, when páramo moved to lower elevation areas such as the inter-Andean valleys (Villota and Behling 2014). Still, the low genetic differentiation for some populations of $D$. alpinus could also be explained by the relatively recent origin of the lineage (6.09 Mya, comparable to some of the individual species within Dercylus). How, then, Dyscolus alpinus has achieved its broad distribution, while Dercylus species have largely remained confined to restricted areas, remains an open question.

Understanding the history of movements and diversification of organisms in alpine tropical ecosystems has considerable importance, given the effects that climate warming is having on high elevation faunas (Moret et al. 2016). Beetle populations in alpine regions of the Andes, including two of the species in this study, are experiencing shifts in elevational range (100-400 m upslope; from grass páramo to super páramo; Moret et al. 2016). A clear picture of 
482 the diversity, distributions and natural history of these páramo species could have important 483 implications towards the conservation of alpine faunas.

484

485

486

487

488

489

490

491

492

493

494

495

496

497

498

499

500

501

502

503

504

505

506

507

508

509

510

511

\section{CONCLUSIONS}

The effects of mountain isolation vary among páramo species. The genetic diversity found in both ground beetle lineages analyzed to date appears to be influenced by the range size and dispersal capability for each beetle lineage. While macropterous species such as Pelmatellus columbianus exhibit broad elevational ranges (from the inter-Andean valleys to páramo, 2000$4200 \mathrm{~m}$ ) and sustain higher levels of gene flow among populations (Muñoz-Tobar, in press), flightless ground beetles display smaller elevational ranges (2750-4200 m) and different degrees of genetic connectivity among populations, from higher levels of genetic connectedness in populations of Dyscolus alpinus, to high levels of differentiation among species and populations within the Dercylus lineage. Although species in the genus Dercylus show similar predicted distributional ranges, less genetic cohesiveness was found among populations, possibly as a result of division of the ecosystem by abrupt topographic features. Species with smaller elevation ranges are probably more susceptible to climate change, and elevational shifts towards higher elevations have been already been reported among ground beetle species from páramo (Moret et al. 2016). The patterns of diversification found from the study of páramo ground beetles have important implications for the conservation of species in this ecosystem, allowing conservation efforts to take into consideration local and regional patterns of diversity. These results show that the loss of wings in flightless ground beetles has not completely limited the dispersal of individuals across páramo patches. However, this study only included two lineages within the ground beetles, analyses of other dispersal-limited organisms is necessary to test these inferences.

\section{ACKNOWLEDGEMENTS}

We are very grateful to the people and institutions who assisted us during the field portion of this study or provided samples for analyses: Andrés Romero-Carvajal (Pontificia Universidad Católica del Ecuador), Shelley Langton-Myers (Clemson University), Pierre Moret (Université Toulouse), Anthony Deczynski (Clemson University), Catalina Bravo (INIAP), Max Ochoa (INIAP) and Rosario Tobar-Ocaña (INIAP). Finally, we thank three anonymous reviewers for feedback that significantly improved the manuscript.

Peer) reviewing PDF | (2019:03:35621:1:1:NEW 14 May 2019) 
512

513

514

515

516

517

518

519

520

521

522

523

524

525

526

527

528

529

530

531

532

533

534

535

536

537

538

539

540

541

542

543

544

545

546

547

548

\section{REFERENCES}

Andújar C, Serrano J, Gámez-Zurita J. 2012. Winding up the molecular clock in the genus Carabus (Coleoptera: Carabidae): assessment of methodological decisions on rate and node age estimation. BMC Evolutionary Biology 12: 40. DOI: 10.1186/1471-2148-12-40.

Baize S, Audin L, Winter T, Alvarado A, Pilatasig Moreno L, Taipe M, Reyes P, Kauffmann P, Yepes H. 2015. Paleoseismology and tectonic geomorphology of the Pallatanga fault (Central Ecuador), a major structure of the South-American crust. Geomorphology 237:14-28. DOI: 10.1016/j.geomorph.2014.02.030.

den Boer PJ, van Huizen THP, den Boer-Daanje W, Aukema B, den Bieman CFM. 1979. Wing polymorphism and dimorphism in Ground Beetles as stages in an evolutionary process (Coleoptera: Carabidae). Entomologia Generalis 6:107-134.

Bohonak AJ, 1999. Dispersal, gene flow, and population structure. The Quarterly Review of Biology 74: 21-45. DOI: 10.1086/392950.

Bouckaert R, Heled J, Kühnert D, Vaughan T, Wu C-H, Xie D, Suchard MA, Rambaut A, Drummond AJ. 2014. BEAST 2: A software platform for Bayesian evolutionary analysis. PLoS Computational Biology 10:e1003537. DOI: 10.1371/journal.pcbi.1003537.

Bousquet Y. 2012. Catalogue of Geadephaga (Coleoptera, Adephaga) of America, North of Mexico. ZooKeys 245:1-1722. DOI: 10.3897/zookeys.245.3416.

Chatzimanolis S, Caterino MS. 2007. Limited phylogeographic structure in the flightless ground beetle, Calathus ruficollis, in southern California. Diversity and Distributions 13:498-509. DOI: 10.1111/j.1472-4642.2007.00352.x.

Chaudoir MD. 1883. Descriptions de Carabiques nouveaux. Coleopterorum Novitates 1:17-39.

Darlington PJ. 1943. Carabidae of mountains and islands: data on the evolution of isolated faunas, and on atrophy of wings. Ecological Society of America 13:37-61. DOI: 10.2307/1943589.

Darwin C. 1859. On the origin of species by means of natural selection, or the preservation of favoured races in the struggle for life. London: John Murray.

Dejean P. 1831. Species général des Coléoptères de la Collection de M. le Baron Dejean. Tome cinquieme. Paris: Méquignon-Marvis.

Elias M, Joron M, Willmott K, Silva- Brandão KL, Kaiser V, Arias CF, Piñerez LMG, Uribe S, Brower AVZ, Freitas AVL, Jiggins CD. 2009. Out of the Andes: Patterns of diversification in clearwing butterflies. Molecular Ecology 18:1716-1729. DOI: 10.1111/j.1365-294X.2009.04149.x.

ESRI. 2016. ArcGIS Desktop Release 10.4.1. Environmental Systems Research Institute. Redlands, CA. 
549

550

551

552

553

554

555

556

557

558

559

560

561

562

563

564

565

566

567

568

569

570

571

572

573

574

575

576

577

578

579

580

581

582

583

584

585

Fick SE, Hijmans RJ. 2017. WorldClim 2: New 1-km spatial resolution climate surfaces for global land areas. International Journal of Climatology 37:4302-4315. DOI: 10.1002/joc.5086.

Gómez-Gutiérrez MC, Pennington RT, Neavez LE, Milne RI, Madriñán S, Richardson JE. 2017. Genetic diversity in the Andes: variation within and between the South American species of Oreobolus. Alpine Botany 127:155-170. DOI: 10.1007/s00035-017-0192-z.

Guayasamin JM, Bonaccorso E, Duellman WE, Coloma LA. 2010. Genetic differentiation in the nearly extinct Atelopus, with emphasis on the A. ignescens and A. bomolochos. Zootaxa 68:55-68. DOI: 10.11646/zootaxa.2574.1.2.

Gutiérrez D, \& Menéndez R. 1997. Patterns in the distribution, abundance and body size of carabid beetles (Coleoptera: Caraboidea) in relation to dispersal ability. Journal of biogeography 24:903-914. DOI: 10.1046/j.1365-2699.1997.00144.x

Hines HM. 2008. Historical biogeography, divergence times, and diversification patterns of bumble bees (Hymenoptera: Apidae: Bombus). Systematic Biology 57:58-75. DOI: 10.1080/10635150801898912.

Homburg K, Drees C, Gossner MM, Rakosy L, Vrezec A, Assmann T. 2013. Multiple glacial refugia of the low-dispersal Ground Beetle Carabus irregularis: molecular data support predictions of species distribution models. PLOS ONE: e61185. DOI: 10.1371/journal.pone.0061185.

Huelsenbeck JP, Ronquist F. 2001. MrBayes: Bayesian inference of phylogenetic trees. Bioinformatics 17:754-755. DOI: 10.1093/bioinformatics/17.8.754. DOI: 10.1093/bioinformatics/17.8.754.

Hughes CE, Atchison GW. 2015. Tansley insight the ubiquity of alpine plant radiations: from the Andes to the Hengduan Mountains. New Phytologist 207:275-282. DOI: 10.1111/nph.13230.

Ikeda H, Nishikawa M, Sota T. 2012. Loss of flight promotes beetle diversification. Nature Communications 3:647-648. DOI: 10.1038/ncomms1659.

Katoh K, Standley DM. 2013. MAFFT multiple sequence alignment software version 7: Improvements in performance and usability. Molecular Biology and Evolution 30:772780. DOI: $10.1093 / \mathrm{molbev} / \mathrm{mst} 010$.

Krabbe N. 2008. Arid valleys as dispersal barriers to high-Andean forest birds in Ecuador. Cotinga 29:28-30.

Kuntzen H. 1912. Beiträge zur kenntnis der Carabidae, I: die gattung Dercylus. Deutsche Entomologische Zeitschrift 1912:575-588.

Laporte FD. 1832. Mémoire sur cinquante espèces nouvelles ou peu connues d'insectes. Annales de la Société entomologique de France 1:386-415.

Larsson SG. 1978. Baltic amber: a palaeobiological study. Entomograph 1:1-192. 
586

587

588

589

590

591

592

593

594

595

596

597

598

599

600

601

602

603

604

605

606

607

608

609

610

611

612

613

614

615

616

617

618

619

620

621

622

Lester S, Ruttenberg B, Gaines SD, Kinlan BP. 2007. The relationship between dispersal ability and geographic range size. Ecology Letters 10:745-758. DOI: 10.1111/j.14610248.2007.01070.x.

Liebherr JK. 1988. Gene flow in Ground Beetles (Coleoptera: Carabidae) of differing habitat preference and flight-wing. Evolution 42:129-137. DOI: 10.1111/j.15585646.1988.tb04113.x.

Luteyn JL. 1999. Paramos: a checklist of plan diversity, geographical distribution and botanical literature. New York City: Memoirs of the New York Botanical Garden.

Maddison DR, Maddison WP. 2015. Zephyr: a Mesquite package for interacting with external phylogeny inference programs Version 1.1.

Madriñán S, Cortés AJ, Richardson JE. 2013. Páramo is the world's fastest evolving and coolest biodiversity hotspot. Frontiers in Genetics 4:1-8. DOI: 10.3389/fgene.2013.00192.

Mcculloch GA, Wallis GP, Waters JM. 2017. Does wing size shape insect biogeography? evidence from a diverse regional stonefly assemblage. Global ecology and biogeography: 93-101. DOI: 10.1111/geb.12529.

Moret P. 2005. Los coleópteros Carabidae del páramo en los Andes del Ecuador. Quito: Museo de Zoología, Centro de Biodiversidad y Ambiente, Escuela de Biología, Pontificia Universidad Católica del Ecuador.

Moret P, Bousquet Y. 1995. Le sous-genre Dercylus (Licinodercylus) Kuntzen, 1912: position systématique, révision des espèces et description de la larve (Carabidae, Dercylini). The Canadian Entomologist 127:753-798. DOI: 10.4039/Ent127753-5.

Muñoz-Tobar SI. (in press) Weak genetic differentiation among populations of the Andean ground beetle Pelmatellus columbianus (Reiche, 1843) (Coleoptera: Carabidae). The Coleopterists Bulletin 73.

Nicholson DB, Ross AJ, Mayhew PJ. 2014. Fossil evidence for key innovations in the evolution of insect diversity. Proceedings of the Royal Society B: Biological Sciences 281:20141823-20141823. DOI: 10.1098/rspb.2014.1823.

Nilsson AN, Petterson RB, Lemdahl G. 1993. Macroptery in altitudinal specialists versus brachyptery in generalists-a paradox of alpine Scandinavian carabid beetles. Journal of Biogeography 20:227-234. DOI: 10.2307/2845674.

Páez-Moscoso DJ, Guayasamin JM. 2012. Species limits in the Andean toad genus Osornophryne (Bufonidae). Molecular Phylogenetics and Evolution 65:805-822. DOI: 10.1016/j.ympev.2012.08.001.

Phillips SJ, Anderson RP, Schapire RE. 2006. Maximum entropy modeling of species geographic distributions. Ecological Modelling 190:231-259. DOI: 10.1016/j.ecolmodel.2005.03.026. 
623

624

625

626

627

628

629

630

631

632

633

634

635

636

637

638

639

640

641

642

643

644

645

646

647

648

649

650

651

652

653

654

655

656

657

658

659

660

Polato NR, Gill BA, Shah AA, Gray MM, Casner KL, Barthelet A, Messer PW, Simmons MP, Guayasamin JM, Encalada AC, Kondratieff BC. 2018. Narrow thermal tolerance and low dispersal drive higher speciation in tropical mountains. Proceedings of the National Academy of Sciences of the United States of America 115:12471-12476. DOI: 10.1073/pnas.1809326115.

Pritchard JK, Stephens M, Donnelly P. 2000. Inference of population structure using multilocus genotype data. Genetics 155:945-959. DOI: 10.1111/j.14718286.2007.01758.x.

Quintana C, Pennington RT, Ulloa CU, Balslev H. 2017. Biogeographic barriers in the Andes: is the Amotape-Huancabamba zone a dispersal barrier for dry forest plants? Annals of the Missouri Botanical Garden 102:542-550. DOI: 10.3417/D-17-00003A.

Rios NE, Bart H. 2010. GEOLocate. Belle Chasse: Tulane University Museum of Natural History.

Rodríguez Saltos CA, Bonaccorso E. 2016. Understanding the evolutionary history of a high Andean endemic: the Ecuadorian hillstar (Oreotrochilus chimborazo). Neotropical Biodiversity 6808:37-50. DOI: 10.1080/23766808.2016.1155280.

Rozas J, Sanchez-DelBarrio JC, Messeguer X, Rozas R. 2003. DnaSP, DNA polymorphism analyses by the coalescent and other methods. Bioinformatics 19:2496-2497. DOI: 10.1093/bioinformatics/btg359.

Schmidt J. 2015. On the Eocene age of Limodromus Motschulsky, 1850, with description of $L$. hoffeinsorum sp. n. from Baltic amber (Coleoptera: Carabidae: Platynini). Zootaxa 3974:573-581. DOI: 10.11646/zootaxa.3974.4.8.

Scudder SH. 1900. Adephagous and clavicorn Coleoptera from the Tertiary deposits at Florissant, Colorado with descriptions of a few other forms and a systematic list of the non-rhynchophorus Tertiary Coleoptera of North America. Monographs of the United States Geological Survey 40:1-148.

Sklenář P, Dušková E, Balslev H. 2011. Tropical and Temperate: Evolutionary History of Paramo Flora. Botanical Review 77:71-108. DOI: 10.1007/s12229-010-9061-9.

Sklenář P, Hedberg I, Cleef AM. 2014. Island biogeography of tropical alpine floras. Journal of Biogeography 41:287-297. DOI: 10.1111/jbi.12212.

Somme L, Block W. 1991. Adaptations to alpine and polar environments in insects and other terrestrial arthropods. In: Lee Y, ed. Insects at low temperature. Boston: Springer Science \& Business Media, 318-359. DOI: 10.1007/978-1-4757-0190-6_14.

Sota T, Nagata N. 2008. Diversification in a fluctuating island setting: rapid radiation of Ohomopterus ground beetles in the Japanese islands. Philosophical Transactions of the Royal Society B: Biological Sciences 363:3377-3390. DOI: 10.1098/rstb.2008.0111.

Stamatakis A. 2014. RAxML version 8: a tool for phylogenetic analysis and post-analysis of large phylogenies. Bioinformatics 30:1312-1313. DOI: 10.1093/bioinformatics/btu033.

Peer] reviewing PDF | (2019:03:35621:1:1:NEW 14 May 2019) 
661 Stone G, French V. 2003. Evolution: have wings come, gone and come again? Current Biology 662 13:436-438. DOI: 10.1016/S0960-9822(03)00364-6.

663 Swets JA. 1988. Measuring the accuracy of diagnostic systems. Science 240:1285-1293. DOI: $664 \quad 10.1126 /$ science. 3287615

665 Vogler AP. 2012. Speciation: don't fly and diversify? Current Biology 22:284-286. DOI: $666 \quad$ 10.1016/j.cub.2012.03.015.

667 Wagner DL, Liebherr JK. 1992. Flightlessness in insects. Trends in Ecology and Evolution 668 7:216-220. DOI: 10.1016/0169-5347(92)90047-F. 
Figure $\mathbf{1}$ (on next page)

Map of the Ecuadorian Andes displaying sites where samples of ground beetles were collected.

A) D. alpinus and B) species in the genus Dercylus. Major geographical barriers examined in the AMOVA are highlighted (east and west cordilleras, rivers and dry valleys). 

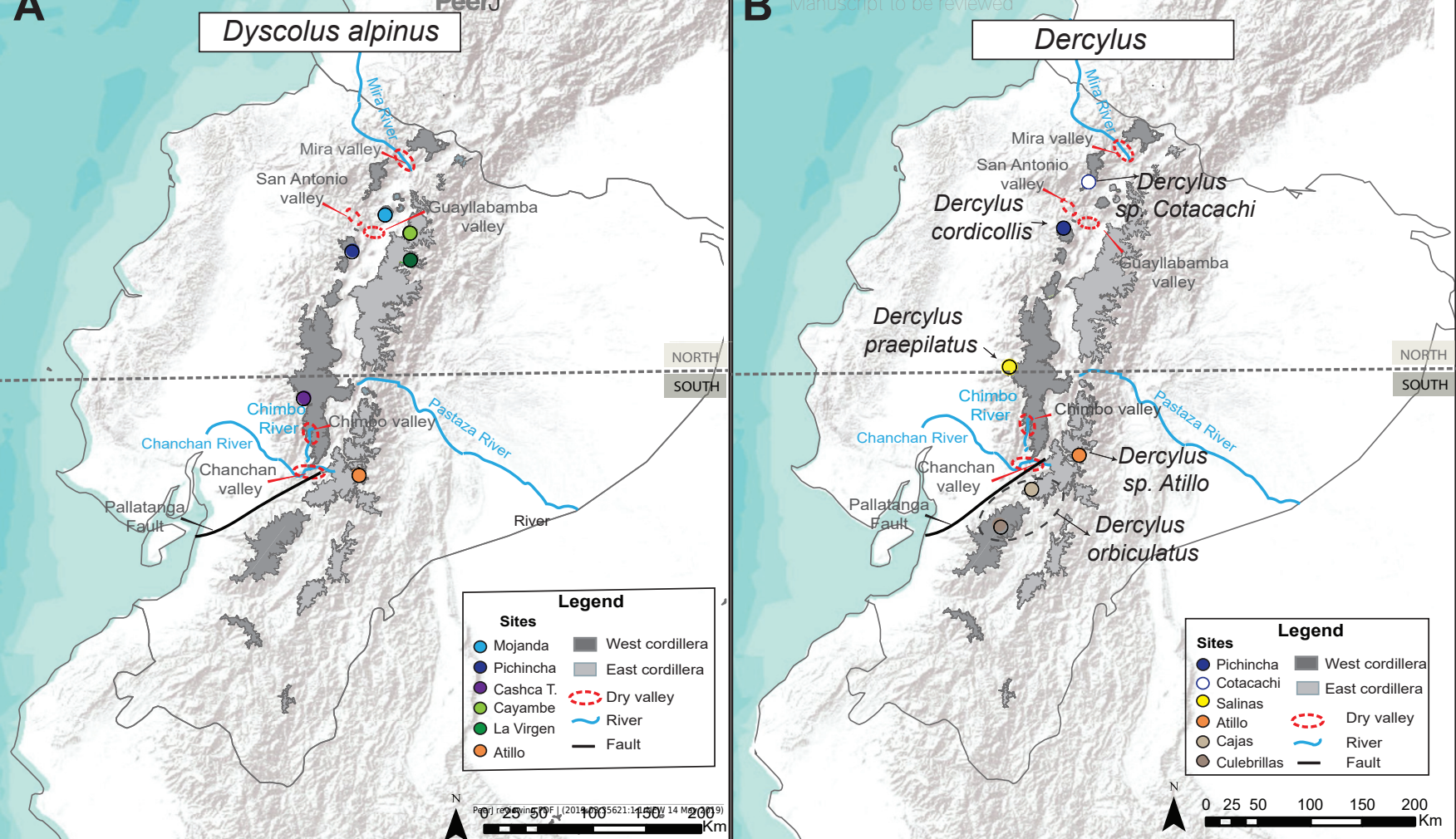
Figure 2 (on next page)

TCS haplotype network for Dyscolus alpinus.
A) COI and B) CAD. 


\section{A - COI

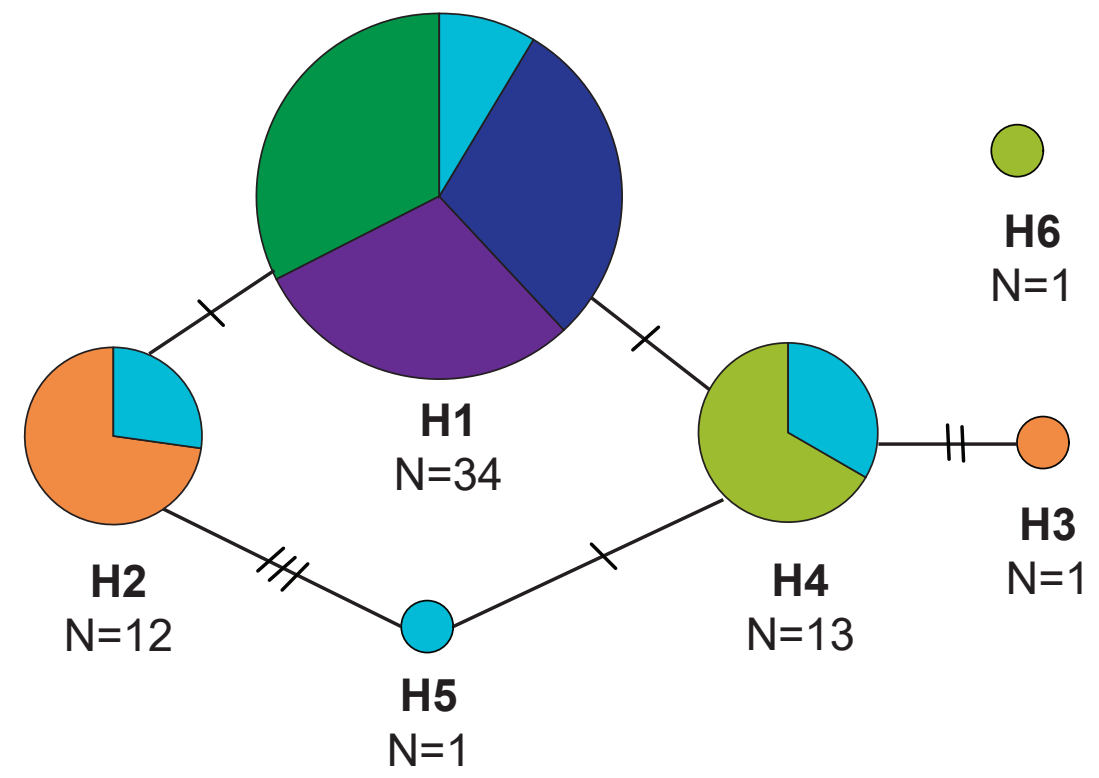

$B$ - CAD

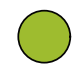

Cashca Totoras Atillo

\section{SITES}

\section{West cordillera East cordillera}

Mojanda Cayambe

Dichincha La Virgen

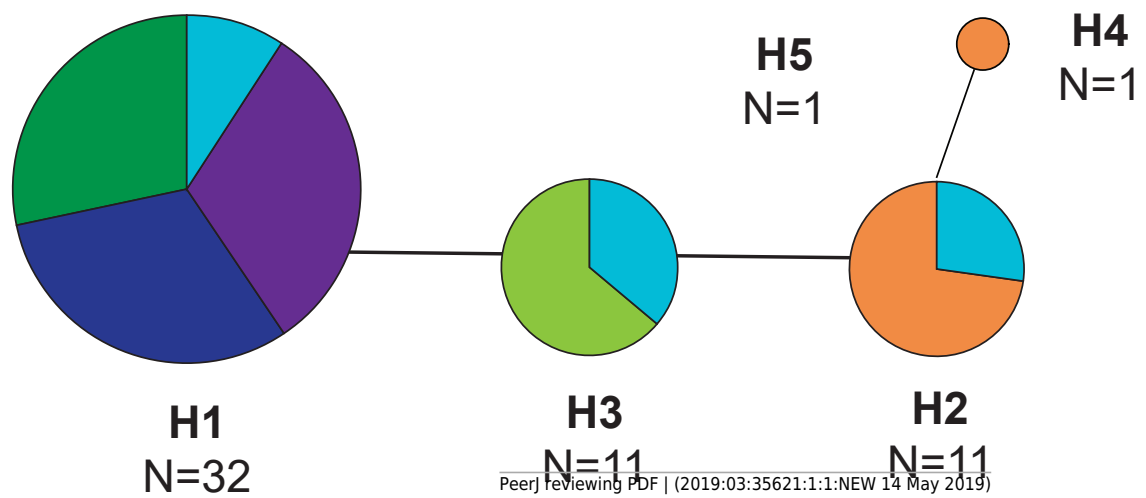


Figure 3 (on next page)

$\phi S T$ values among populations of Dyscolus alpinus A) COI and B) CAD. 


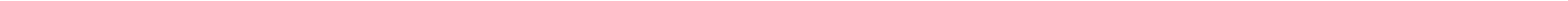


Figure 4 (on next page)

TCS haplotype network for species in Dercylus lineage.
A) COI and B) CAD. 
A Perol

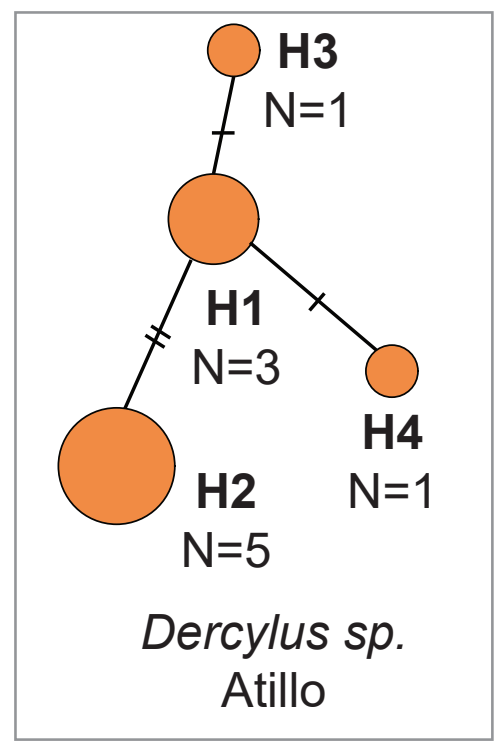

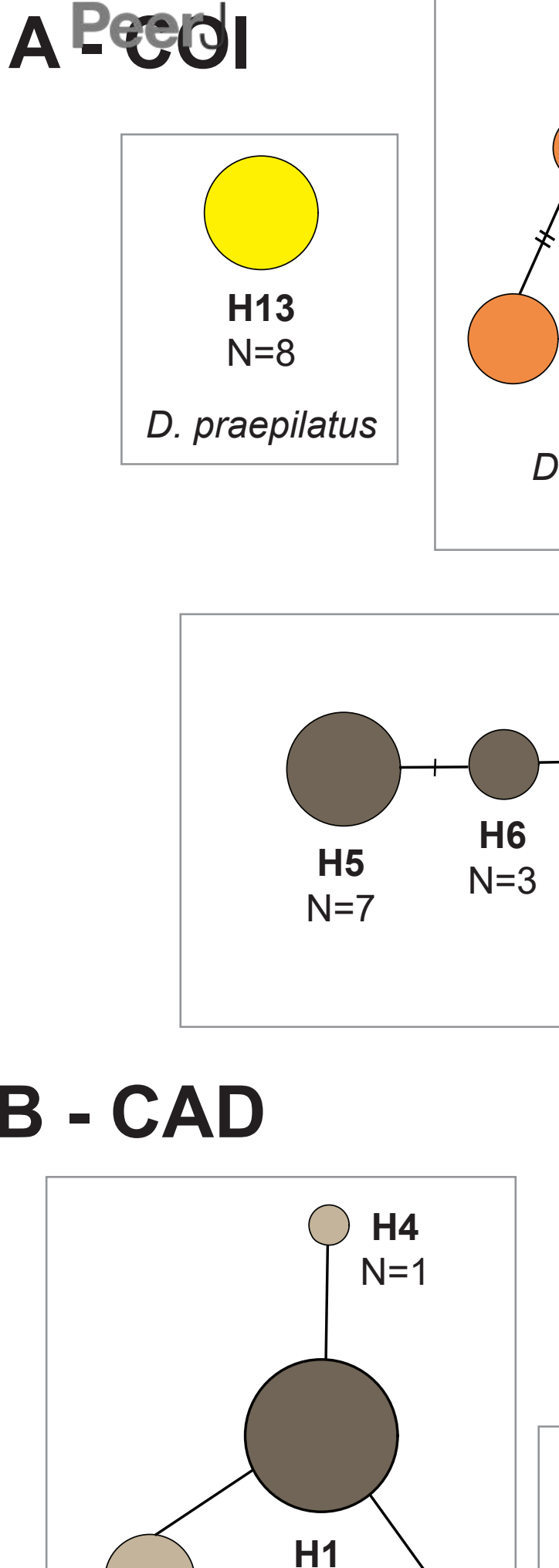
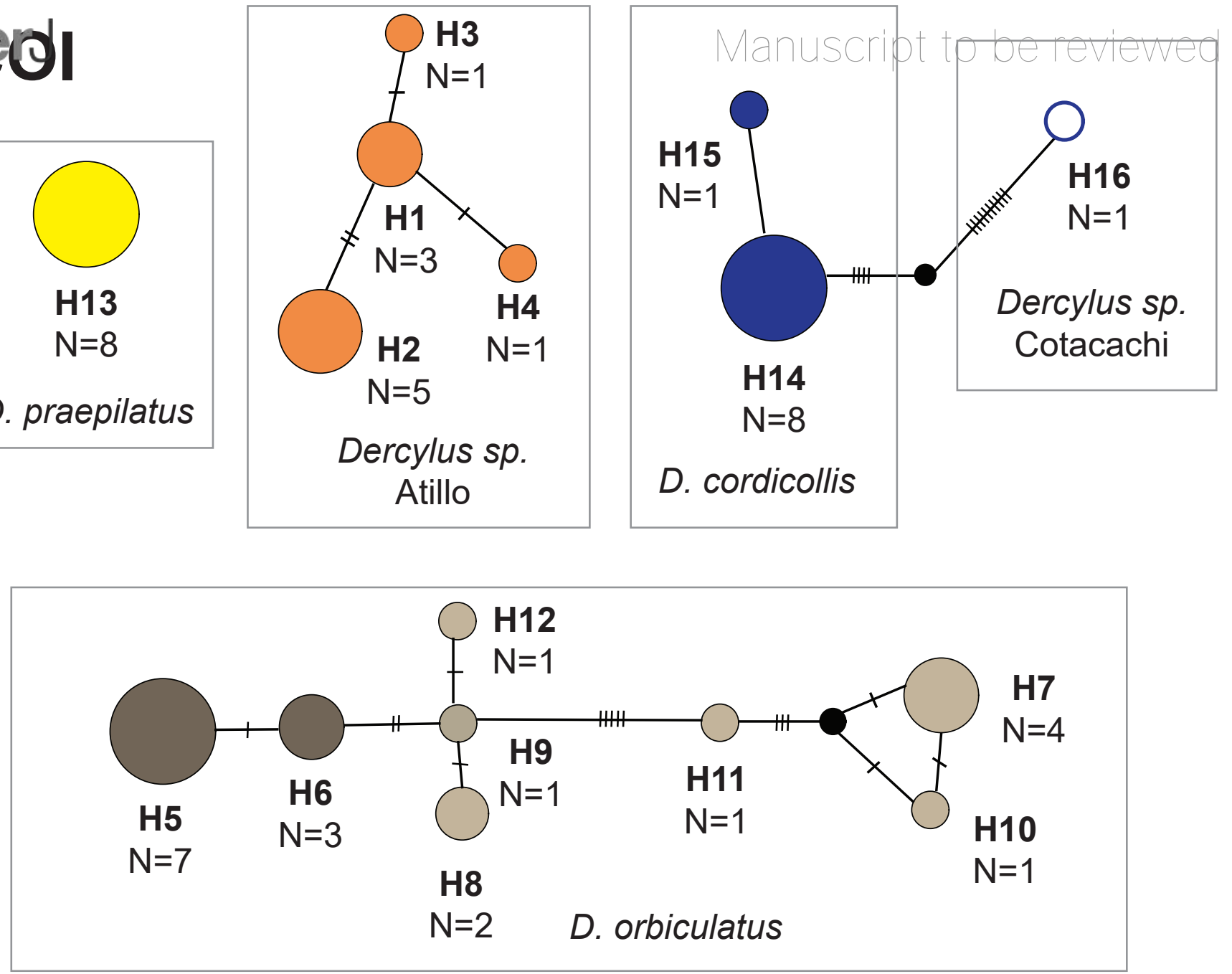

$B$ - CAD

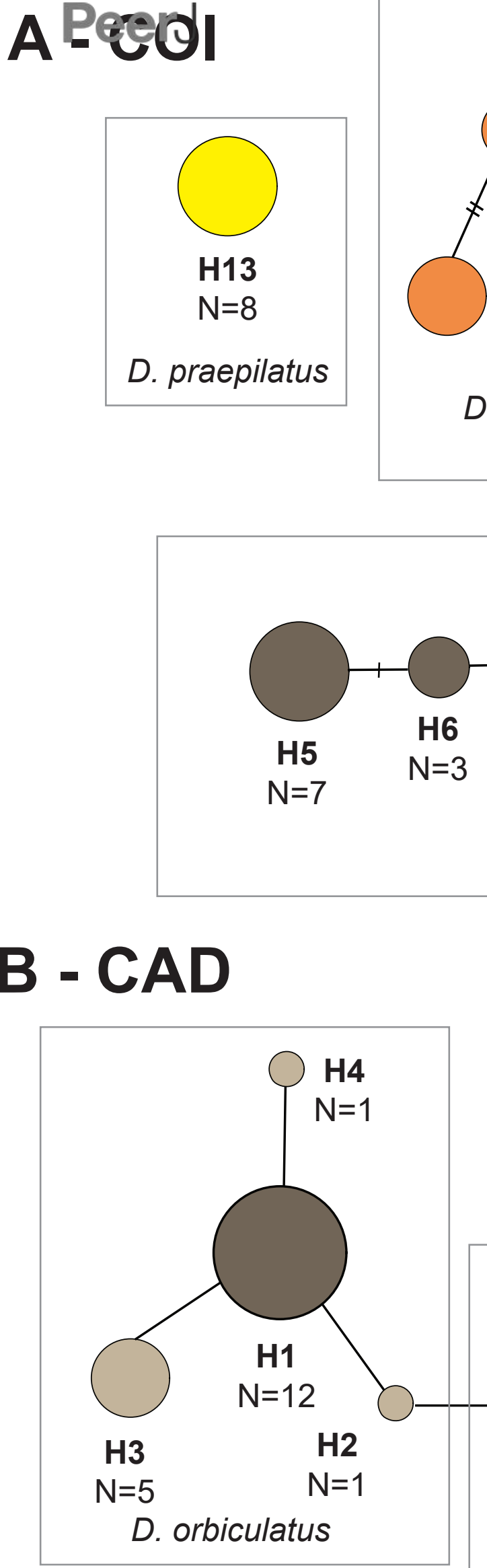

\section{D. cordicollis + Dercylus from Cotacachi}

\section{SITES}

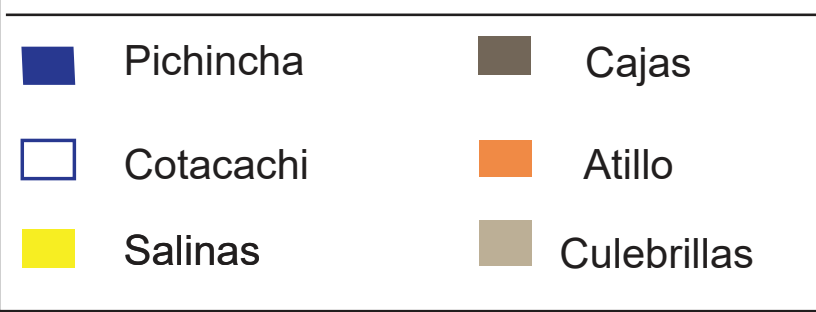


Figure $\mathbf{5}$ (on next page)

Bayesian $50 \%$ rule consensus tree for $D$. alpinus.

A) $\mathrm{COI}$ and B) CAD, were phylogenetic analysis included one sample of each haplotype. Site information for each haplotype is presented as colored bars for each gene tree, and in parentheses directionally (North, North West and South East) is shown, and haplotypes present in multiple sites were labeled as mixed. Posterior probabilities are shown above the branches and bootstrap support values for the ML tree are shown below branches. 
Figure 6 (on next page)

Timing of the $D$. alpinus clade lineage based on a relaxed molecular clock for both genes.

Voucher numbers (Supplemental Table S1) and haplotype designation are recorded at the end for each member of Dyscolus clade. For each sample the first haplotype corresponds to the mitochondrial data set, followed by the nuclear haplotype (e.g. SIMT208H6H5), with exception of SIMT028 were only the mtDNA was amplified. 


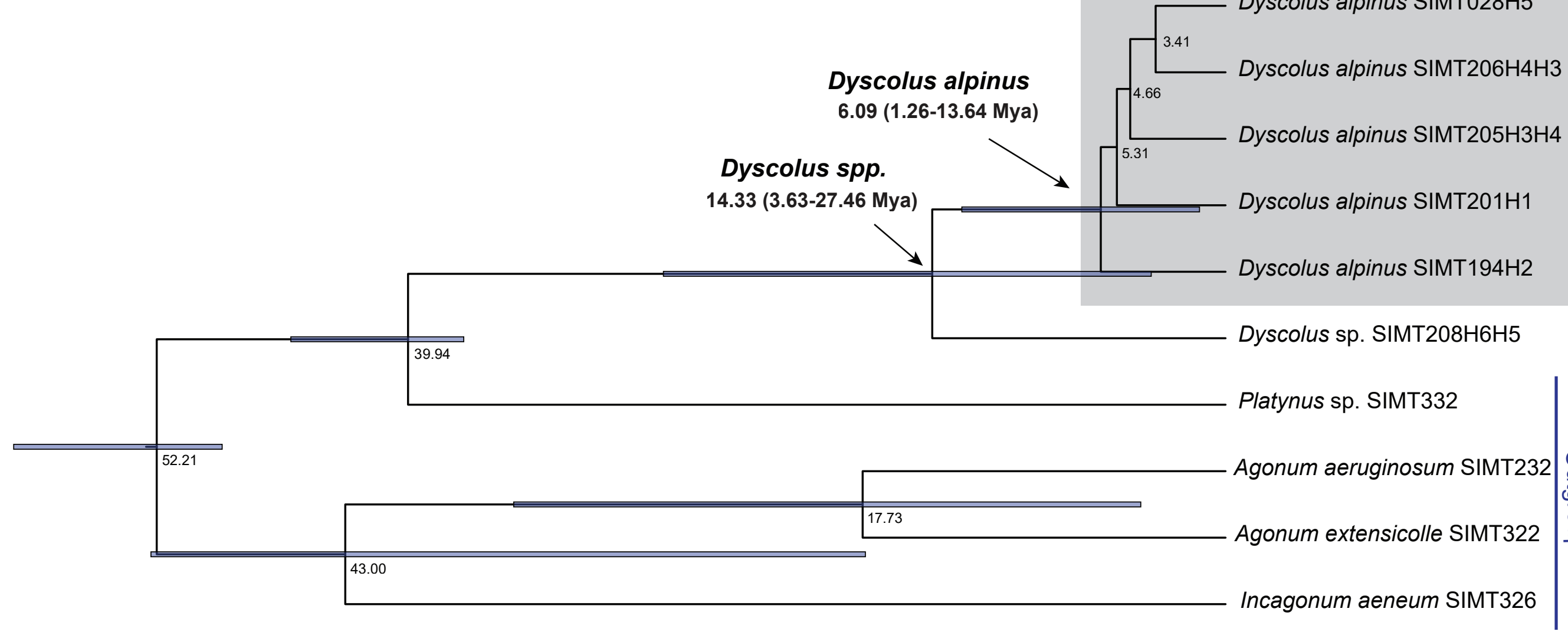

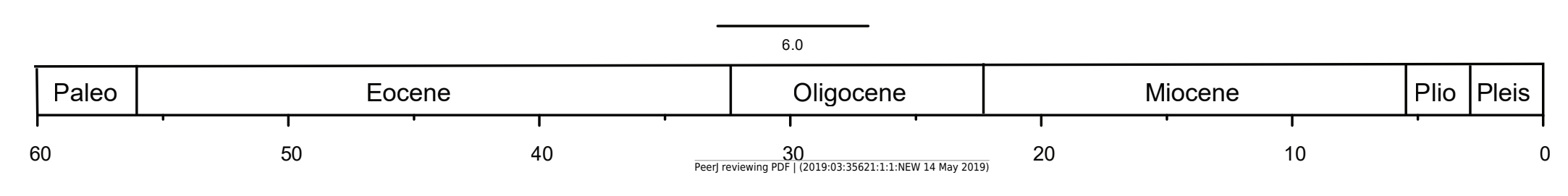


Figure 7 (on next page)

Bayesian 50\% rule consensus tree for species of Dercylus.

A) $\mathrm{COI}$ and B) CAD. Posterior probabilities are shown above the branches and bootstrap support values for the ML tree are shown below branches. Colored boxes around clades indicate localities as shown in the legend. 
A - C'OPirJ

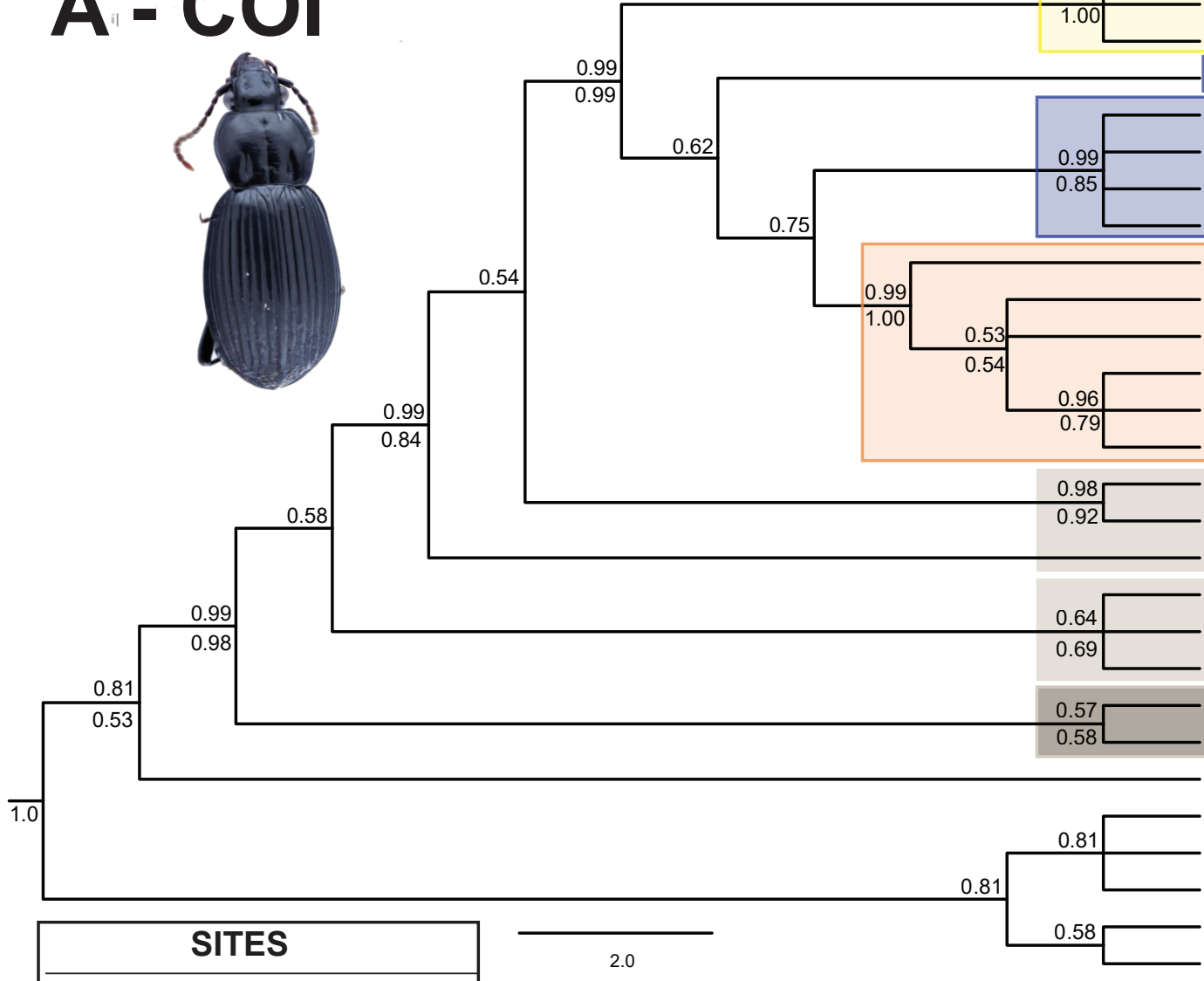

Dercylus sp. Cotacachi SIMT265H16

D. cordicollis SIMT313H14

Dercylus sp.

Cotacachi

cordicollis SIMT263H15

D. cordicollis SIMT261H14

D. cordicollis SIMT259H 14

Dercylus sp. Atillo SIMT221H4

Dercylus

cordicollis

- Dercylus sp. Atillo SIMT212H1

Dercylus sp. Atillo SIMT216H3

Dercylus sp. Atillo SIMT220H2

Dercylus sp. Atillo SIMT219H2

Dercylus sp. Atillo SIMT213H2

D. orbiculatus SIMT242H10

D. orbiculatus SIMT258H1

D. orbiculatus SIMT244H11

D. orbiculatus SIMT230H9

D. orbiculatus SIMT245H12

D. orbiculatus SIMT243H8

D. orbiculatus SIMT237H5

D. orbiculatus SIMT225H6

Dicaelus elongatus SIMT329

Dercylus sp Atillo

Notonomus sp.

Sarticus obesulus

Loxodactylus carinulatus

Amara sp. SIMT334

Oodes amaroides SIMT328

Pichincha Cajas

Cotacachi Atillo

Salinas Culebrillas

\section{$B$ - CAD}
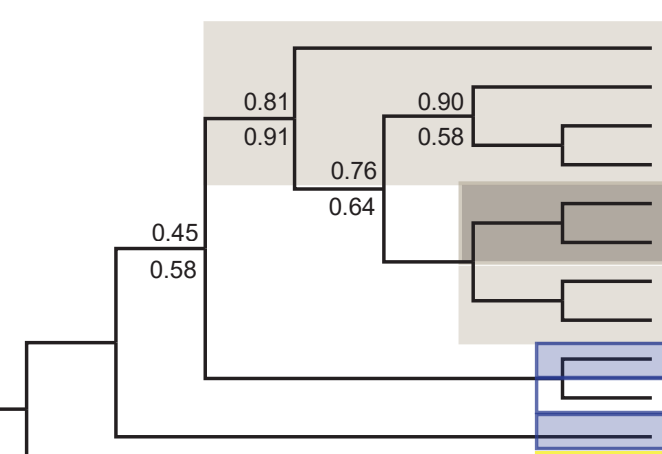

D. orbiculatus SIMT242H2H10

D. orbiculatus SIMT230H3H9

D. orbiculatus SIMT243H3H8

D. orbiculatus SIMT245H3H12

D. orbiculatus SIMT225H1H6

D. orbiculatus SIMT237H1H5

D. orbiculatus SIMT244H1H11

D. orbiculatus SIMT258H4H1

Dercylus cordicollis SIMT313H5H14

Dercylus sp. Cotacachi SIMT265H5H16

Dercylus cordicollis SIMT261H6H14

D. praepilatus SIMT338H8H13

D. praepilatus SIMT337H11H13

D. praepilatus SIMT234H13H13

Dercylus cordicollis SIMT263H7H15

Dercylus cordicollis SIMT259H7H14

Dercylus sp. Atillo SIMT219H10H2

Dercylus sp. Atillo SIMT213H11H2

Dercylus sp. Atillo SIMT212H11H1

- Dercylus sp. Atillo SIMT220H8H2

Dercylus sp. Atillo SIMT221H9H4

Dercylus sp. Atillo SIMT216H12H3

Loxodactylus carinulatus

$0.59 \longleftarrow$ Loxodactylus ca

1.0

Sarticus obesulus

Amara apicaria SIMT334

Dicaelus elongatus SIMT329

Peerfreviewing PDF | (2019.03.350620 1:1:NEV 14 May 2019)

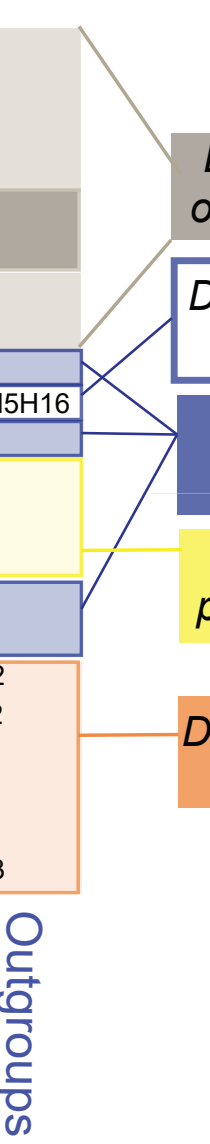

Dercylus orbiculatus

Dercylus sp.

Cotacachi

Dercylus

cordicollis

Dercylus

praepilatus

Dercylus sp.

Atillo 
Figure 8 (on next page)

BEAST tree for Dercylus based on a relaxed molecular clock for both genes.

Voucher number (Supplemental Table S1) and haplotype designation are recorded at the end of each individual in the genus Dercylus. For each sample the first haplotype corresponds to the mitochondrial data set, followed by the nuclear haplotype (e.g. SIMT212H1H11). 
Manuscript to be reviewed
Dercylus sp. Atillo

6.04 (1.13-12.90 Mya)

Dercylus sp. Atillo SIMT212H1H11

\begin{tabular}{l|l}
3.28 \\
\hline
\end{tabular} $\rightarrow$
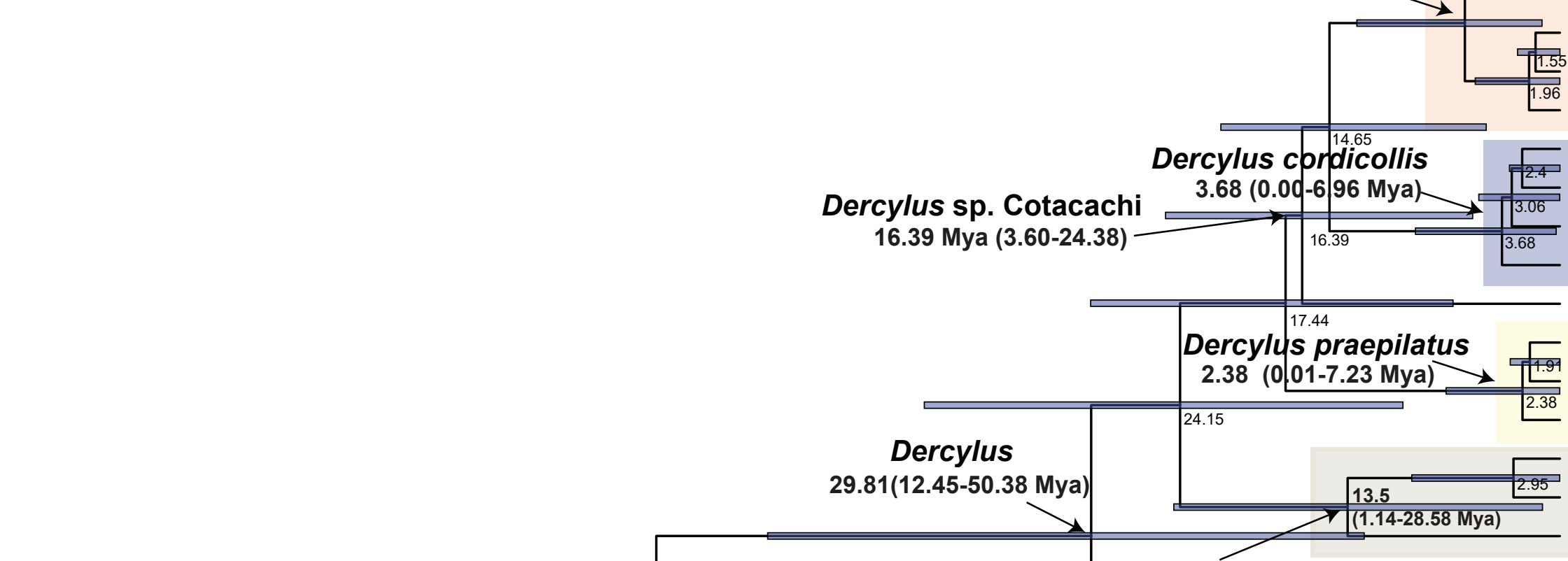

D. cordicollis SIMT263H15H7

Dercylus sp. Cotacachi SIMT265H16H5
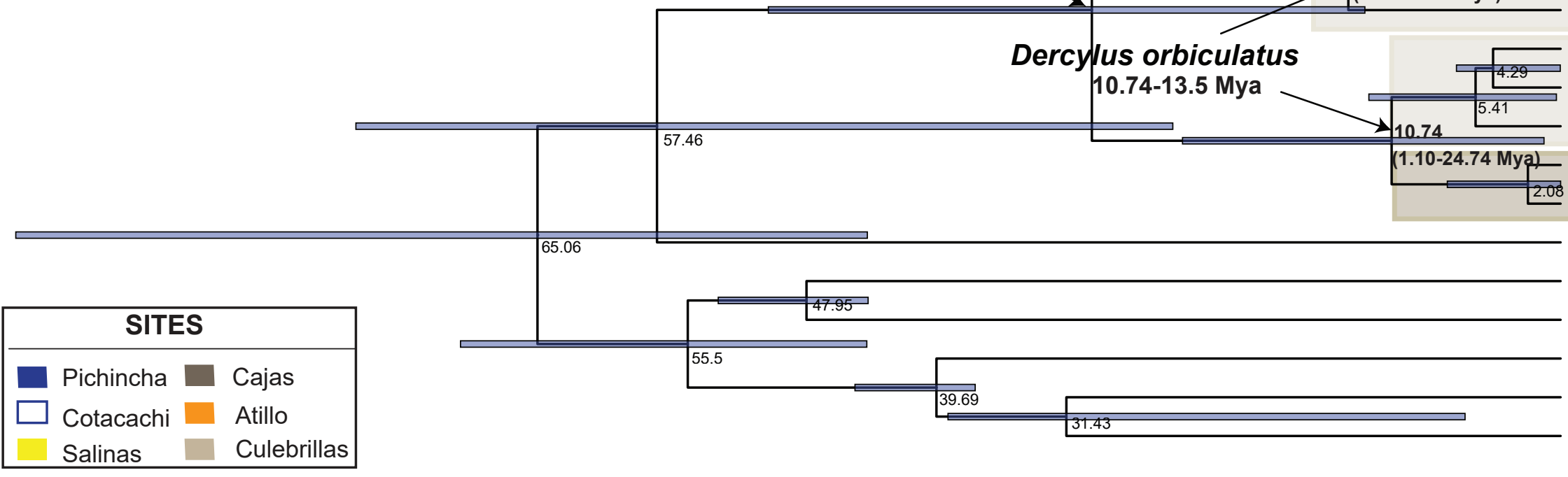

SIMT225H6H1

Dicaelus elongatus SIMT329

Amara apicaria SIMT334

Oodes amaroides SIMT328

Sarticus obesulus

Notonomus sp.

Loxodactylus carinulatus

7.0

\begin{tabular}{|c|c|c|c|c|c|c|c|}
\hline \multicolumn{3}{|c|}{ Cretaceous } & Paleocene & Eocene & Oligocene & Miocene & Plio Plei \\
\hline
\end{tabular}


Figure 9 (on next page)

Maximum entropy models for present distribution for species in the genus Dercylus across the Ecuadorian Andes using five bioclimatic variables.

A) D. orbiculatus, B) D. cordicollis and C) D. praepilatus, Colored points represent localities included in the model. Shaded areas represent the broader predicted distribution across the northern Andes. 


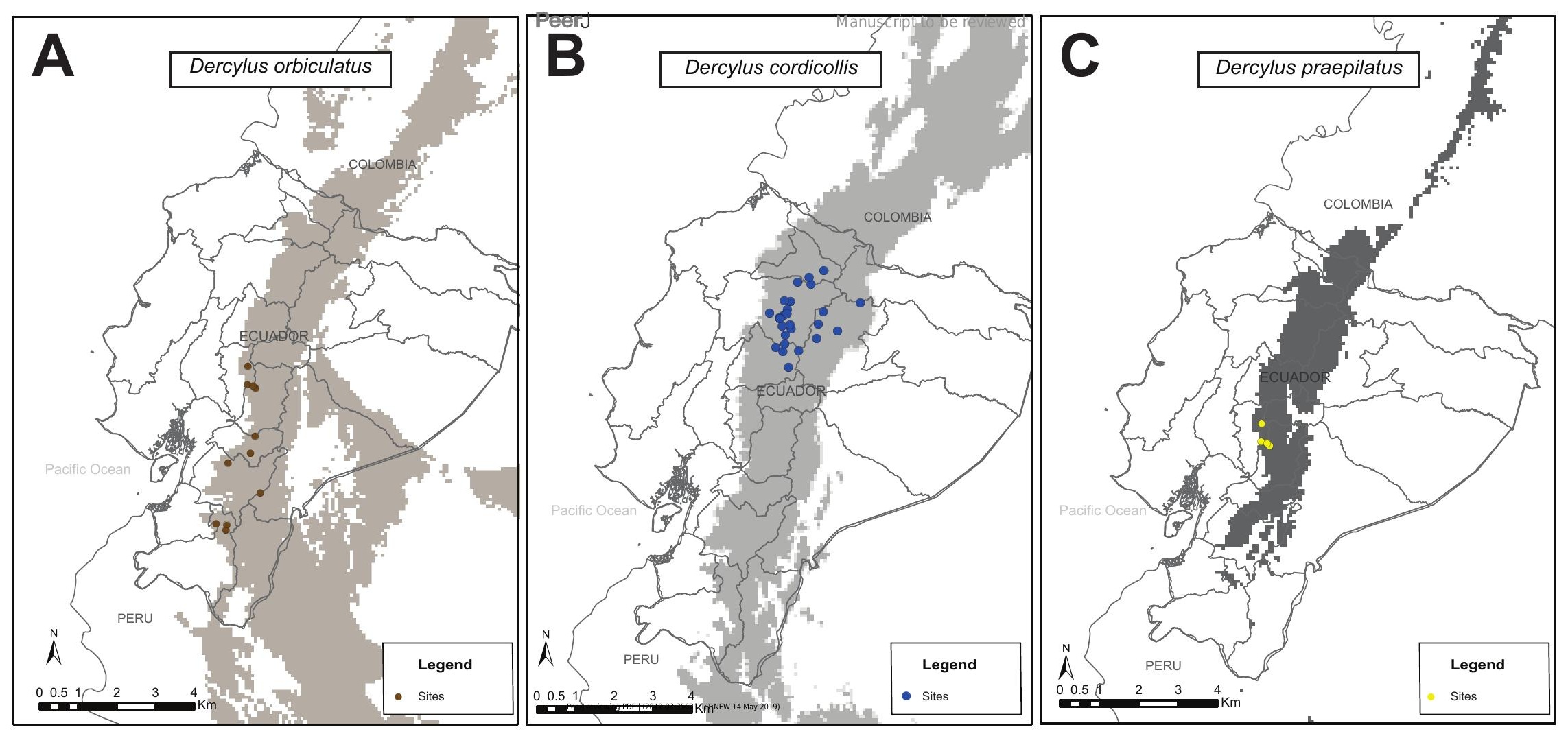




\section{Table $\mathbf{1}$ (on next page)}

Summary of the collecting sites from the Ecuadorian Andes, from which ground beetle species where collected for genetic analysis.

Data set compiled from 2015 to 2016. 


\begin{tabular}{|c|c|c|c|c|c|c|}
\hline No. & Region & Site Name & Latitude & Longitude & $\begin{array}{c}\text { Elevation } \\
\text { (m) }\end{array}$ & Col. Date \\
\hline 1 & \multirow{5}{*}{$\begin{array}{l}\text { West } \\
\text { Mountain } \\
\text { range }\end{array}$} & Mojanda & $\mathrm{N} 00^{\circ} 08.710^{\prime}$ & W78 $16.753^{\prime}$ & 3715 & 12-Jul-2016 \\
\hline 2 & & Pichincha & $\mathrm{S} 00^{\circ} 11.259^{\prime}$ & W78 $32.432^{\prime}$ & 3897 & 22-Jun-2016 \\
\hline 3 & & Salinas & $\mathrm{S} 1^{\circ} 24^{\prime} 11.03^{\prime \prime}$ & $\mathrm{W} 78^{\circ} 14.051^{\prime}$ & 3604 & 11-Jun-2015 \\
\hline 4 & & $\begin{array}{l}\text { Cashca } \\
\text { Totoras }\end{array}$ & $\mathrm{S} 01^{\circ} 43.485^{\prime}$ & W78 $78^{\circ} .183^{\prime}$ & 3509 & 13-Jun-2015 \\
\hline 5 & & Cajas & $\mathrm{S} 02^{\circ} 47.020^{\prime}$ & $\mathrm{W}^{\prime} 9^{\circ} 13.438^{\prime}$ & 3956 & 20-Jun-2015 \\
\hline 6 & \multirow{5}{*}{$\begin{array}{l}\text { East } \\
\text { Mountain } \\
\text { range }\end{array}$} & Cayambe & $\mathrm{S} 00^{\circ} 02.101^{\prime}$ & $\mathrm{W} 78^{\circ} 03.608^{\prime}$ & 3743 & 01-Jun-2016 \\
\hline 7 & & La Virgen & S00 $18.477^{\prime}$ & $\mathrm{W}^{\prime} 8^{\circ} 13.953^{\prime}$ & 3694 & 28-Jun-2016 \\
\hline 8 & & Atillo & $\mathrm{S} 02^{\circ} 11.265^{\prime}$ & W78 $31.2601^{\prime}$ & 3501 & 07-Jul-2016 \\
\hline 9 & & Culebrillas & $\mathrm{S} 02^{\circ} 28.337^{\prime}$ & W78 $73.719^{\prime}$ & 3799 & 15-Jun-2015 \\
\hline 10 & & Cotacachi & N00¹9.79952' & $\mathrm{W}^{\prime} 8^{\circ} 20.80830^{\prime}$ & 3757 & 13-Jul-2016 \\
\hline
\end{tabular}

1 


\section{Table 2 (on next page)}

Overview of the genetic diversity indexes for $D$. alpinus and Dercylus species and populations.

$\mathrm{N}$; refers to the number of individuals sampled; S; number of segregating sites; $h$ haplotypic diversity; $\pi$, is a measure of nucleotide diversity; $D$, represents the Tajima's $D$ a neutrality test statistics with its corresponding p-value, and F, represents Fu's Fs. 


\begin{tabular}{|c|c|c|c|c|c|c|c|c|c|c|c|c|c|}
\hline \multirow[b]{2}{*}{ Species } & \multirow[b]{2}{*}{ Site } & \multirow[b]{2}{*}{$\mathrm{N}$} & \multirow[b]{2}{*}{$\mathrm{h} \pm \mathrm{SD}$} & \multicolumn{3}{|c|}{$\mathrm{COI}$} & \multicolumn{7}{|c|}{$\mathrm{CAD}$} \\
\hline & & & & $\pi \pm \mathrm{SD}$ & $\mathrm{S}$ & $\mathrm{D}$ & $\mathrm{F}$ & $\mathrm{N}$ & $\mathrm{h} \pm \mathrm{SD}$ & $\pi \pm \mathrm{SD}$ & $\mathrm{S}$ & $\mathrm{D}$ & $\mathrm{F}$ \\
\hline \multirow{12}{*}{$\begin{array}{l}\text { Dyscolus } \\
\text { alpinus }\end{array}$} & Mojanda & 11 & $0.71 \pm 0.05$ & $0.01 \pm 0.00$ & 10 & 0.87 & 1.35 & 10 & $0.91 \pm 0.04$ & $0.01 \pm 0.00$ & 36 & -1.24 & -0.25 \\
\hline & & & & & & $(p=0.82)$ & $(p=0.23)$ & & & & & $(p=0.68)$ & $(p=0.18)$ \\
\hline & Pichincha & 9 & $0.19 \pm 0.11$ & $0.01 \pm 0.00$ & 1 & -1.11 & -0.34 & 11 & $0.40 \pm 0.18$ & $0.00 \pm 0.00$ & 2 & -1.40 & -1.16 \\
\hline & & & & & & $(p=0.17)$ & $(p=0.33)$ & & & & & $(p=0.04)^{*}$ & $(p=0.19)$ \\
\hline & C. Totoras & 10 & $0.19 \pm 0.11$ & $0.00 \pm 0.00$ & 1 & -1.11 & -0.34 & 10 & $0.20 \pm 0.01$ & $0.00 \pm 0.00$ & 1 & -0.59 & -0.09 \\
\hline & & & & & & $(p=0.19)$ & $(p=0.33)$ & & & & & $(p=0.19)$ & $(p=0.35)$ \\
\hline & Cayambe & 10 & $0.20 \pm 0.15$ & $0.01 \pm 0.02$ & 30 & -2.09 & -5.18 & 8 & $0.23 \pm 0.13$ & $0.00 \pm 0.00$ & 11 & -0.85 & -5.96 \\
\hline & & & & & & $(\mathrm{p}=0.00)^{* *}$ & $(\mathrm{p}=0.01)^{* *}$ & & & & & $(\mathrm{p}=0.01)^{* *}$ & $(p=0.00)^{*}$ \\
\hline & La Virgen & 11 & $0.00 \pm 0.00$ & $0.00 \pm 0.00$ & 0 & 0.00 & 0.00 & 11 & $0.00 \pm 0.00$ & $0.00 \pm 0.00$ & 0 & 0.00 & 0.00 \\
\hline & & & & & & $(p=1.00)$ & $(p=1.00)$ & & & & & $(p=1.00)$ & $(p=1.00)$ \\
\hline & Atillo & 10 & $0.61 \pm 0.16$ & $0.00 \pm 0.01$ & 9 & -1.47 & -8.45 & 9 & $0.21 \pm 0.12$ & $0.00 \pm 0.00$ & 0 & -1.11 & -0.01 \\
\hline & & & & & & $(p=0.05)^{*}$ & $(\mathrm{p}=0.00)^{* *}$ & & & & & $(p=0.18)$ & $(p=0.36)$ \\
\hline \multicolumn{14}{|l|}{ Dercylus } \\
\hline \multirow[t]{4}{*}{ D. orbiculatus } & Cajas & 10 & $0.51 \pm 0.09$ & $0.00 \pm 0.00$ & 2 & 0.33 & 0.07 & 10 & $0.00 \pm 0.00$ & $0.00 \pm 0.00$ & 0 & 0.00 & 0.00 \\
\hline & & & & & & $(p=0.81)$ & $(p=0.29)$ & & & & & $(p=1.00)$ & $(p=1.00)$ \\
\hline & Culebrillas & 10 & $0.86 \pm 0.07$ & $0.01 \pm 0.01$ & 15 & 2.26 & 4.43 & 9 & $0.21 \pm 0.12$ & $0.00 \pm 0.00$ & 1 & -1.08 & -0.01 \\
\hline & & & & & & $(p=0.05)^{*}$ & $(p=0.03)^{*}$ & & & & & $(p=0.19)$ & $(p=0.36)$ \\
\hline D. cordicollis & Pichincha & 10 & $0.21 \pm 0.12$ & $0.00 \pm 0.00$ & 1 & -1.08 & -0.01 & 8 & $0.66 \pm 0.07$ & $0.15 \pm 0.00$ & 2 & 1.64 & 0.96 \\
\hline & & & & & & $(p=0.19)$ & $(p=0.36)$ & & & & & $(p=0.95)$ & $(p=0.03)^{*}$ \\
\hline D proanilatus & Salinas & 8 & $0.00 \pm 0.00$ & $0.00 \pm 0.00$ & 0 & 0.00 & 0.00 & 5 & $0.00 \pm 0.00$ & $0.0 \pm 0.00$ & 0 & 0.00 & 0.00 \\
\hline 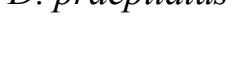 & & & & & & $(p=1.00)$ & $(p=1.00)$ & & & & & $(p=1.00)$ & $(p=1.00)$ \\
\hline Dercylus sp. & Atillo & 10 & $0.73 \pm 0.08$ & $0.00 \pm 0.00$ & 4 & 0.78 & 0.86 & 10 & $0.35 \pm 0.11$ & $0.02 \pm 0.00$ & 1 & 0.01 & 0.70 \\
\hline
\end{tabular}




\begin{tabular}{|c|c|c|c|c|c|c|c|c|c|c|c|c|c|}
\hline & & & & & & $(\mathrm{p}=0.66)$ & $(\mathrm{p}=0.25)$ & & & & & $(\mathrm{p}=0.73)$ & $(\mathrm{p}=0.39)$ \\
\hline Dercylus sp. & Cotacachi & 1 & $0.00 \pm 0.00$ & $0.00 \pm 0.00$ & 0 & $\begin{array}{c}0.00 \\
(p=1.00)\end{array}$ & $\begin{array}{c}0.00 \\
(p=1.00)\end{array}$ & 1 & $0.00 \pm 0.00$ & $0.0 \pm 0.00$ & 0 & $\begin{array}{c}0.00 \\
(p=1.00)\end{array}$ & $\begin{array}{c}0.00 \\
(\mathrm{p}=1.00)\end{array}$ \\
\hline
\end{tabular}
1 


\section{Table 3(on next page)}

Analysis of the molecular variance for populations of $D$. alpinus. 


\begin{tabular}{|c|c|c|c|c|c|c|c|c|}
\hline \multirow{2}{*}{$\begin{array}{l}\text { No. } \\
\text { groups }\end{array}$} & \multirow[b]{2}{*}{ Partitions } & \multirow[b]{2}{*}{ Tests } & \multicolumn{3}{|c|}{$\mathrm{COI}$} & \multicolumn{3}{|c|}{ CAD } \\
\hline & & & $\begin{array}{l}\text { Among } \\
\text { groups }\end{array}$ & $\begin{array}{l}\text { Among } \\
\text { populations }\end{array}$ & $\begin{array}{l}\text { Within } \\
\text { populations }\end{array}$ & $\begin{array}{l}\text { Among } \\
\text { groups }\end{array}$ & $\begin{array}{l}\text { Among } \\
\text { populations }\end{array}$ & $\begin{array}{l}\text { Within } \\
\text { populations }\end{array}$ \\
\hline 2 & $(1,2,4)(6,7,8)$ & $E-W$ & -1.51 & 3.96 & 97.55 & -1.51 & 3.96 & 97.55 \\
\hline 2 & $(1,2,6,7)(8,7)$ & $\mathrm{N}-\mathrm{S}$ & -0.41 & 19.64 & 80.77 & 2.47 & 1.65 & 95.88 \\
\hline 2 & $(8)(1,2,4,6,7)$ & 7 vs all & 11.5 & 14.32 & 74.18 & -5.91 & 5.21 & 100.7 \\
\hline 2 & (4) $(1,2,6,7,8)$ & 4 vs all & -8.14 & 23.15 & 84.99 & 24.89 & -6.11 & 81.22 \\
\hline 4 & $(1,2)(4)(6,7)(8)$ & Barriers 1 & -10.11 & 28.36 & 81.76 & 10.31 & -6 & 95.69 \\
\hline 3 & $(1,2)(4)(6,7,8)$ & Barriers 2 & -13.96 & 30.42 & 83.54 & 12.39 & -6.31 & 93.92 \\
\hline 4 & $(1,2,4)(6)(7)(8)$ & Barriers 3 & 10.91 & 10.36 & 78.74 & -11.65 & 12.18 & 99.47 \\
\hline
\end{tabular}




\section{Table 4(on next page)}

$\phi_{S T}$ values of $D$. alpinus for COI (lower diagonal) and CAD (upper diagonal) genes. 


\begin{tabular}{l|cccccc}
\hline Populations & 1 & 2 & 4 & 6 & 7 & 8 \\
\hline 1. MO & - & -0.02 & 0.50 & 0.22 & 0.22 & 0.15 \\
2. PI & 0.50 & - & 0.53 & 0.31 & 0.01 & 0.00 \\
4. CT & 0.32 & 0.90 & - & -0.08 & 0.65 & 0.62 \\
6. CY & 0.10 & 0.56 & 0.40 & - & 0.40 & 0.40 \\
7. LV & 0.50 & -0.10 & 0.88 & 0.55 & - & 0.01 \\
8. AT & 0.40 & 0.86 & 0.81 & 0.50 & 0.85 & -
\end{tabular}

1 


\section{Table 5 (on next page)}

Analysis of the molecular variance for populations and species of Dercylus. 


\begin{tabular}{|c|c|c|c|c|c|c|c|c|}
\hline \multirow{2}{*}{$\begin{array}{l}\text { No. } \\
\text { groups }\end{array}$} & \multirow[b]{2}{*}{ Partitions } & \multirow[b]{2}{*}{ Tests } & \multicolumn{3}{|c|}{$\mathrm{COI}$} & \multicolumn{3}{|c|}{ CAD } \\
\hline & & & $\begin{array}{l}\text { Among } \\
\text { groups }\end{array}$ & $\begin{array}{l}\text { Among } \\
\text { populations }\end{array}$ & $\begin{array}{l}\text { Within } \\
\text { populations }\end{array}$ & $\begin{array}{l}\text { Among } \\
\text { groups }\end{array}$ & $\begin{array}{l}\text { Among } \\
\text { populations }\end{array}$ & $\begin{array}{l}\text { Within } \\
\text { populations }\end{array}$ \\
\hline 2 & $(2,3,5,10)(8,9)$ & $E-W$ & -11.28 & 102.46 & 8.82 & -63.40 & 154.07 & 9.34 \\
\hline 2 & $(2,3,10)(5,8,9)$ & N-S & 11.89 & 80.09 & 8.02 & 30.61 & 62.93 & 6.46 \\
\hline 2 & $(8)(2,3,5,9,10)$ & 8 vs all & 35.57 & 55.23 & 9.20 & -6.07 & 98.29 & 7.76 \\
\hline 4 & $(2,10)(3)(5,9)(8)$ & Barriers 1 & 66.33 & 25.88 & 7.78 & 93.82 & -0.37 & 6.55 \\
\hline 3 & $(2,10,3)(5)(9)(8)$ & Barriers 2 & 10.86 & 80.79 & 8.35 & 94.46 & -0.60 & 6.14 \\
\hline \multirow[t]{2}{*}{5} & $(2,10)(3)(5)(9)(8)$ & Barrier 3 & 22.59 & 68.99 & 8.42 & 96.81 & -4.26 & 7.45 \\
\hline & $(2)(10)(3)(5,9)(8)$ & Barriers 4 & 73.18 & 19.05 & 7.78 & 93.12 & 0.25 & 6.63 \\
\hline 2 & $(5,9)(3,5,8,10)$ & 8,9 vs all & 26.22 & 10.43 & 11 & -31.50 & 122.97 & 8.53 \\
\hline
\end{tabular}




\section{Table 6(on next page)}

$\square_{\text {st }}$ values for species of Dercylus COI (lower diagonal) and CAD (upper diagonal) genes. 


\begin{tabular}{l|cccccc}
\hline \multicolumn{1}{c|}{ Populations } & 2 & 3 & 5 & 8 & 9 & 10 \\
\hline 2. D. cordicollis - Pichincha & - & 0.00 & 1.00 & 0.06 & 0.95 & 0.00 \\
3. D. praepilatus - Salinas & 0.99 & - & 1.00 & 0.03 & 0.95 & 0.00 \\
5. D. orbiculatus - Cajas & 0.98 & 0.60 & - & 0.93 & 0.10 & 1.00 \\
8. Dercylus spp. Atillo & 0.96 & 0.97 & 0.96 & - & 0.90 & -0.77 \\
9. D. orbiculatus - Culebrillas & 0.80 & 0.84 & 0.60 & 0.85 & - & 0.92 \\
10. Dercylus spp. Cotacachi & 0.98 & 1.00 & 0.98 & 0.95 & 0.71 & - \\
\hline
\end{tabular}

1 